\title{
Electricity or the Environment: A Study of Public Regulation Without Public Control
}

\author{
Clifford P. Case, III \\ and David Schoenbrod*
}

Regulation permeates almost every aspect of the power industry, including its relationship with the environment. Yet, paradoxically, government makes practically no public or conscious decisions on the key issues of electric power and environment. First, both by statutory design and administrative choice, regulation focuses on narrow, defined topics, defaulting on the critical broad issues through indecision and accretion. Thus, numerous agencies project in great detail the future demand for power, but none grapples with how much power consumption should grow. Second, regulators eliminate effective public participation in the decisionmaking they do undertake by shifting the time of actual decisions from statutorily prescribed hearings to earlier negotiations, by restricting the public availability of usable information, and by creating procedural obstacles to public participation.

These inethods for avoiding open resolution of hard issues flow logically from industry's desire for autonony and regulators' distaste for making difficult decisions in public, and reflect the imbalance of usable political power that exists between the regulated industry and the public. Energy companies, conbined into trade associations, can muster significant resources to fight every issue from beginning to end, while consumers and environmentalists, individually with little power, can jell into effective opposition only on the intermittent occasions where discontent on a colorful issue reaches exasperation.

This constant pressure inclines the regulators to consider the regulated their prime constituents. Differences are resolved in private

* Respectively, Assistant Counsel, Office of General Counsel, New York State Urban Development Corporation, and Staff Attorney, Natural Resources Defense Council, Inc. The authors served as staff attorneys for the Special Committee on Electric Power and the Environment of The Association of the Bar of the City of New York from the fall of 1971 to the summer of 1972. The views expressed herein are those of the authors and are in no way intended to reflect the views of the Special Committee or any other organization.

Copyright, 1973, Clifford P. Case, III, and David Schoenbrod. 
negotiations, thereby allowing the agency and the company to present a united front during public hearings. Intervenors are then left with their own limited resources for gathering information sufficient to mount a challenge. Opposition is further scattered by framing the issue in a way that avoids the toughest, most critical issues. Thus, the process asks, "do you want this plant to operate now or do you want a future blackout," not, "do you want many more power plants over the next decade or a slow-down in the growth of electricity consumption?"

The existing decisionmaking process worked well enough for industry until recent years. But when environmental groups started to gather the resources to challenge a few percent of all proposed plants, utilities began to see the fragmented decisionmaking process as a potential source of delay, not a means for diffusing governmental authority. The electric industry then mounted pressure for legislative action to deal with delay-the symptom of the administrative disease.

Some new legislation seeuns imminent, especially since environmentally oriented congressinen have also introduced legislation designed to rationalize planning for electricity and the environment. There have been many studies of the problem, imcluding Electricity and the Environment, ${ }^{1}$ a report by the Special Committee on Electric Power and the Environment of The Association of the Bar of the City of New York, for which we worked as staff attorneys in 1971 and $1972 .^{2}$

1. Special Committee on Electric Power and the EnVIRonment, The AsSOCiation OF THE BAR OF tHe CITY OF NEW YoRK, Electricity aNd tHe ENvironMENT: THE REFORM OF LEGAL INSTITUTIONS (1972) [hereinafter cited as CoMmitTEE REPORT].

2. This Article is based in part on the CoMmitre Reporr, and supports many of its recommendations, including:

(1) treatment of all energy forms within a single regulatory structure, instead of the present system of different agencies for different energy forms;

(2) creation of separate federal bodies to handle regulatory and promotional duties for energy matters, instead of requiring a single agency to both regulate and promote, as at present;

(3) explicit consideration by a federal commission of whether the present rapidly rising rate of energy consumption is in the national interest, followed by congressional action on commission recommendations;

(4) placing responsibility for licensing of power plants and transmission lines with a state land-use commission instead of with the state public utilities commission;

(5) preserving the right of independent state environmental protection agencies to review power facilities for compliance with environmental standards, rather than giving that right to the state public utilities commission or the state land-use commission; and

(6) opening up agency proceedings to public scrutmy at an earlier stage of the proceedings than at present.

We do not believe, however, that the report was on the whole responsive to correcting the critical defects in the current process. For example, the report identifies the rapidly increasing rate of demand for energy as an issue, but fails to take the cssential next step of recognizing that governmental action, such as an initial small energy tax, is necessary to moderate this demand. The report also givcs lip service to the desirability 
All of these attempts at regulatory reform fall short because they fail to grapple with the fundamental imbalance of usable political power. Any workable solution must take account of this imbalance. As such, it must force the process to deal with the avoided issues, to facilitate public participation, and to thrust the resolution of issues into public view. In essence, the imbalance of power requires a rethinking of the administrative process in all its areas of application.

This Article, however, looks only at electricity and the environment. The inethod of analysis avoids tracking individual agency decisions, since such an approach defines the issues as the agency does, and fails to show why a series of seemingly rational separate decisions by numerous regulatory bodies can achieve such absurd results as lengthy delays or the complete neglect of broad environmental issues. This Article begins instead by defining the problein in terms of the key functional issues concerning electric power and the environment and then seeks to determine how these issues are resolved, whether by one or many agencies or by collective inaction.

Accordingly, Part I identifies the issues raised by the interaction of electricity and the environment. Part II describes the present decisionmaking process. Part III then shows how this process avoids the most important issues. Part IV argues that when agencies decide issues consciously they do so outside public view. Parts V and VI indicate how the failure to disclose information and other obstacles to public participation perpetuate decisionmaking in private. The environmentalists' response is described in Part VII. Finally, Part VIII comments on pending legislation, and Part IX contams suggestions for reform.

I.

\section{The Conflict Between Electric Power and the Environment}

Modern society relies on electric power. A power blackout highlights how many aspects of industry, commerce, agriculture, transportation, health care, and home life depend on electricity. ${ }^{3}$ But supply-

of public participation, but ensures that this participation will remain imeffective by failing to provide for adequate sources of funds or institutional support within government for representatives of the public. Nor need the public be admitted, according to the report, to the stage of agency proceedings where most decisions are madenamely, the staff and industry negotiations that precede formal applications for licenses.

These particular failures in the report of the Special Committee flow from a general failure to recognize both the seriousness of environmental problems caused by energy production and the weakness of governmental institutions-bodies that are supposed to protect the public interest but which, in practice, become champions of the very industries they were intended to regulate. This Article attempts to demonstrate why past government regulation has failed to accomplish its goals and suggests possible reforms.

3. For a survey of the relationship of electricity and the economy, see CommrrTEE REPORT 17-27. 
ing electricity causes environmental damage. Harm occurs at all stages of the fuel cycle of electricity, from the mine to the power plug. For example, extraction and preparation of fuels like coal, oil, gas, and uranium create harmful side-effects on both land and water. ${ }^{4}$ Burning of fossil fuels yields air pollution and waste heat. ${ }^{5}$ Nuclear power plants produce even inore waste heat than fossil-fueled plants and pose the additional hazard of radiation exposure. ${ }^{B}$ Moreover, use of plutonium as a fuel for nuclear plants will necessitate large reserves, which might be stolen and used to make an atomic bomb. ${ }^{7}$ And finally, all power plants and transmission lines require large amounts of land, while hydroelectric developinents impinge particularly on wild or scenic areas. $^{9}$

Legions of studies document the impact of these harmful consequences, but some examples will demonstrate the magnitudes involved. One proposed power project would produce more air pollutants than are now emitted from all sources in the air basin surrounding Los Angeles. ${ }^{10}$ Transmission lines in this country now occupy a land area the size of Counecticut. ${ }^{11}$ And it is projected that the routine permissible radioactivity resulting from nuclear power sources will cause from 3,000 to 15,000 deaths froin cancer annually. ${ }^{12}$

Utilities and environmentalists have joined issue over whether requested plants and transmission lines should be licensed. While all inajor blackouts have been caused by equipment breakdowns, not licensing delays, ${ }^{13}$ utilities warn that failure to license new plants could cause blackouts or brownouts in the future. ${ }^{14}$ Environmentalists dispute these

4. See id. at 32-33.

5. See id. at 28-32, 41-42.

6. See id. at 33-35.

7. See id. at 37 .

8. See id. at $43-44$.

9. See id. at $42-43$.

10. Letter concerning the North Central Power Project, located in North Dakota and Montana, from the Environmental Defense Fund to the Director of Region VII of the Bureau of Reclamation, Aug. 28, 1972.

11. COMMITTEE REPORT 19.

12. Advisory Commttieg on the Biological EFfects of IonizTno Radiation, National Academy of Sciences/National Researci Council, The Efrects on Populations of Exposure to Low LeVELs of IonizING RADIATION 2, 91 (1972).

13. Both of the largest U.S. blackouts, that of November, 1965 in the northeastern United States and Canada, and that of 1967 in Pennsylvania, New Jersey and the Delaware-Maryland-Virginia peninsula, were caused by transmission failures. FEDERAL Power Commission, 1 Prevention of Power Fallures 1 (1967); testimony of W.B. McGuire in Hearings on H.R. 5277, H.R. 6970, H.R. 6971, H.R. 6972, H.R. 3838, H.R. 7045, H.R. 1079, and H.R. 1486 Before the Subcomm. on Communications and Power of the House Comm. on Interstate and Foreign Commerce, 92d Cong., 1st Sess., ser. 92-32 at 685-86 (1971) [hereinafter cited as Hearings on Plant Siting].

14. E.g., National Electric Reliability Council, "Impact of A 12-Month Delay of New Nuclear and Fossil-Fired Steam Generating Units" (Feb. 1972). 
claims and insist that whatever benefits the proposed facilities will produce cannot justify the irreparable environmental damage they will cause. Utilities respond that the public demands vast increases in electricity output, and unavoidable problems are not germane to whether a plant should be licensed. The conflict extends not only to whether plants should be built, but how. Environmentalists want devices installed to clean up emissions from fossil plants and to cool heated water before it is discharged into lakes and streams. Utilities often reply that such equipment is unreliable and too expensive to the ultimate consumer.

The conflict, moreover, will escalate. Electricity consumption now grows at a rate of seven percent annually, yielding a doubling of consumption each decade. ${ }^{15}$ This growth would require over seven times more electricity by the century's end than is produced now. Yet utilities already have difficulty finding suitable sites for generating and transmission facilities. Technological development will be challenged just to keep environmental effects at current levels, much less reduce them. Utilities urge greater governmental funding while environmentalists contend that too much money is now spent to support the nuclear community and not enough to develop potentially less polluting methods such as solar and fusion power.

II.

\section{THE REgULATORY FRAMEWORK}

Production and transmission of electric power is carried on within a complex web of federal, state, and local regulation. This regulatory scheme has developed piecemeal over the years in response to various perceived crises caused by utility monopolization and by clashes between electricity production and the environment or public safety. Initiative in most areas still lies with the utility, which decides if new generating and transmission facilities are needed and then plans the type of plant and the location. Various governmental agencies review these decisions and monitor facilities once they start operating.

Review occurs at the federal level when new facilities are licensed. The Atomic Energy Commission (AEC) issues licenses for nuclear plants, the Federal Power Commission (FPC) for hydroelectric plants, and the Army Corps of Engineers for all types of plants, including conventional fossil-fueled plants. All three agencies must comply with the

15. Resources for the Future, Inc., ENergy Research NeEds I-6-7 (1971). Energy consumption for generating electricity is, moreover, increasing faster than electricity consumption itself, and currently, the rate of increase in energy consumption for generating electricity is itself increasing. Cook, The Flow of Energy in an Industrial Society, 224 SCIENTIFIC AMERICAN 137 (Sept. 1971). 
National Environmental Policy Act (NEPA). ${ }^{16}$ NEPA requires federal agencies, before undertaking "major Federal actions significantly affecting the liuman environment," 17 including the issuance of licenses, ${ }^{18}$ to prepare an "impact statement" describing the effects of the proposed action on the environment, proposing possible alternatives, and comparing the effects of short-term uses of environmental resources with long-term needs.

\section{A. The Atomic Energy Commission}

Under the Atomic Energy Act of $1954,{ }^{10}$ the Atomic Energy Commission regulates the safety of nuclear activities, including power plants. The most significant of the many AEC approvals a nuclear plant inust receive are the construction permit and the operating license. ${ }^{20}$ Although the review process is formally divided into two stages, in practice it is continuous, starting even before a utility formally applies to the AEC's Division of Reactor Licensing (DRL) for a construction permit. After informal conferences witl DRL, the utility submits a construction permit application for review by the DRL staff. Differences between staff and applicant are then ironed out through further conferences and correspondence. The utility must include with eacls application an Environmental Report covering the same issues that the AEC must cover in its own impact statement under NEPA. ${ }^{21}$ The DRL staff prepares a draft impact statement which is circulated for comment and then made fimal. ${ }^{22}$

In addition to undergoing DRL staff review, applications also must be submitted to the Advisory Committee on Reactor Safeguards (ACRS), a group of 15 specialists from disciplines concerned with nuclear safety. ${ }^{23}$ On the basis of the application and discussions with DRL staff and the applicant (public participation is limited), the ACRS reports directly to the AEC whether the proposed facility can be operated without undue risk to the public. The ACRS and the DRL staff need not agree, but in fact they have only differed twice. ${ }^{24}$

16. 42 U.S.C. $\$ \$ 4321-47$ (1970).

17. Id. $\$ 4332(2)(\mathrm{C})$.

18. 36 Fed. Reg. 7724 (1971).

19. Atomic Energy Act of $1954 \S \S 1-233$ [hereinafter AEA], 42 U.S.C. $\S \S$ 2011-281 (1970).

20. For a detailed description of the AEC licensing process, see Murphy, Atomic Safety and Licensing Boards: An Experiment in Administrative Decision Making on Safety Questions, 33 LAw \& CoNTEMP. Prob. 566 (1968).

21. 10 C.F.R. $\$$ 50, App. D(A)1 (1972).

22. $I d . \S 8$.

23. AEA \& 182(b), 42 U.S.C. \$ 2232(b) (1970).

24. See COMMTTEe REPORT 71-72. Until recently, no public participation in ACRS proceedings was permitted. The proceedings now have been opened up somo 
After staff review is complete, a public hearing must be held, whether or not one is requested. ${ }^{25}$ Although a contest theoretically may occur between the applicant and the staff, at a hearing no applicant has ever continued to press his application in the face of staff opposition. ${ }^{26}$ Hence, objections to an application expressed at a public hearing will come only from intervenors. ${ }^{27}$

Hearings are held before a three-person Atomic Safety and Licensing Board (ASLB) composed of two persons with technical qualifications and a third who is "qualified in the conduct of administrative proceedings." 28 Heavy reliance is placed on written testimony, including the application, environmental impact statement, and staff safety analysis. Lacking expert witnesses, intervenors usually concentrate on cross-examination on these documents. At the close of the hearing the ASLB issues an initial decision. ${ }^{29}$ Appeals are heard by an Atomic Safety and Licensing Appeal Board ${ }^{30}$ and then by a federal court of appeals. ${ }^{31}$

When construction of a plant is nearly complete, the utility applies for an operating license. The review process is similar to that for the construction perinit, except that a hearing is not inandatory. ${ }^{32}$ Under legislation passed in the summer of $1972,{ }^{33}$ the AEC can einploy a truncated proceeding, including a shortened hearing, to issue a temporary operating license where operation of the new facility is essential to ensure an adequate and reliable power supply. ${ }^{34}$

\section{B. The Federal Power Commission}

Under the Federal Power Act, ${ }^{35}$ hydroelectric plants on navigable

what, apparently due to passage of the Federal Advisory Committee Act, Pub. L. No. 92-463, 86 Stat. 770 (Oct. 6, 1973). See Nucleonics Week (Feb. 15, 1973), at $1-2$.

25. AEA $\$ 189,42$ U.S.C. $\$ 2239$ (1970).

26. In one case before the $\mathrm{AEC}$ concerning Consolidated Edison's Indian Point II nuclear plant, lowever, the utility is opposing the staff's recommendations on building cooling towers.

27. Notice of the learing must be given at least 30 days in advance. 10 C.F.R. $\S 2.104$ (1972). The AEC rules of practice allow for prehearing discovery, similar to that available under the Federal Rules of Civil Procedure, but only on motion. Id. $\S \S 2.740-44$.

28. $\S \S 2.740-44$. A petition to intervene may be filed by "any person whose interest may be affected." 10 C.F.R. $\$ 2.714$ (1972).

29. Id. $\S \S 2.760,2.764$.

30. Id. $\S \S 2.785,2.786$.

31. AEA § 189(b), 42 U.S.C. \& 2239(b) (1970).

32. Id. \& 189(a), 42 U.S.C. $\$ 2239$ (a).

33. AEA \& 192, 42 U.S.C. \& 2242 (Supp. 1973).

34. AEA $\$ 192$ (b) (3), 42 U.S.C. $\$ 2242$ (b) (3) (Supp. 1973).

35. Federal Power Act $\S \S 1-320$ [hereinafter FPA], 16 U.S.C. $\$ \S 791 a-825 r$ (1970). 
waters and public lands or reservations require FPC licenses. ${ }^{36}$ The major grounds for granting a license are that the project is "desirable and justified in the public interest," 37 and that it will best contribute to a compreliensive plan to improve a waterway for purposes of commerce, power, recreation, and "other beneficial public uses." 38

Since the FPC staff holds meetings and discussions with a license applicant to resolve differences, ${ }^{39}$ the final staff and applicant positions are generally identical. Initial FPC practice under NEPA was to rely on the applicant's environmental impact statement, but NEPA has been held to require independent staff preparation of an impact statement. ${ }^{40}$ Hearings are not required under the Act, but the Commission usually orders hearings after completion of staff review if opponents have asked to intervene. ${ }^{41}$ The learing is held before an FPC hearing examiner, ${ }^{42}$ who makes the initial decision in the proceeding. ${ }^{43}$ Appeal can be made to the Commission itself, and judicial review can be sought in a federal court of appeals. ${ }^{44}$

\section{The Corps of Engineers}

The authority of the Corps of Engineers stems from the Rivers and Harbors Appropriation Act of 1899 (also known as the Refuse

36. FPA $\S 4,16$ U.S.C. $\S 797$ (1970). The FPC's jurisdiction includes both conventional dams and pumped storage projects. FPC v. Union Electric Co., 381 U.S. 90 (1965), rehearing denied, 381 U.S. 956 (1965).

37. FPA \& 4(e), 16 U.S.C. $\$ 797(\mathrm{e})(1970)$.

38. FPA $\S 10$ (a), 16 U.S.C. $\$ 803$ (a) (1970). Courts have held that these standards require the FPC to consider the short- and long-term impact of a project, environmental factors, and alternative sources for the power, Scenic Hudson Prcservation Conf. v. FPC, 354 F.2d 608 (2d Cir. 1965), cert. denied, 384 U.S. 941 (1966) (sctting aside an FPC licensing order for failure to compile a sufficient rccord, ignoring relevant factors, and not studying available alternatives), including the alternative of no plant at all. Udall v. FPC, 387 U.S. 428, 448 (1967). An FPC license application, therefore, must include economic, technical, and environmental information, and must describe the applicant's plans for recreational facilities at the project site. FPA \$ 9, 16 U.S.C. $\$ 802(1970)$.

39. Interviews with FPC staff in Washington, D.C., Jan. 6, 1972.

40. Greene County Planning Bd. v. FPC, 455 F.2d 412 (2d Cir. 1972), cert. denied, 409 U.S. 849 (1972) (holding the FPC abdicated its responsibility by using the license applicant's impact statement rather than compiling its own). After a license application is filed, notice must be given in writing to states and inunicipahities likely to be interested in or affected by the application and must be published in a local newspaper serving the project site. FPA $\$ \$ 4(e)-(f), 16$ U.S.C. $\$ \S 797(e)-(f)(1970)$. Ncither the Act nor the FPC's rules require the Commission to permit intervention, but it usually does so if a petitioner can demonstrate an interest in the project. While voluntarily permitting intervention, lowever, the Commission has resisted prehearing discovery, even though such discovery is provided for in its rules. See COMMTTten REPORT 81.

41. See COMMITTE REPORT 81.

42. 18 C.F.R. $\$ \S 1.20(c), 1.27$ (1972).

43. Id. $\$ 1.83$.

44. FPA $\$ 313(b), 16$ U.S.C. $\$ 825 l(b)$ (1970). 
Act) ${ }^{45}$ and has grown over the years as new statutes and decisions have been superimposed on old. No structure may be erected in navigable waters without the Corps' approval. ${ }^{46}$ Corps sanction, therefore, is necessary for almost all large steam generating plants, whether fossilor nuclear-fueled, because such structures must draw in cooling water. The extent of Corps authority over hydroelectric developments which are within the FPC's jurisdiction is unclear.

The requirement of a Corps construction permit would not be of major significance if the only criterion for issuance were the effect of the structure on navigation. Zabel v. Tabb ${ }^{47}$ held, however, that NEPA requires the Corps to prepare an environmental impact statement before a permit can be issued. Thus, $Z$ abel requires, for the first time, federal review of the environmental impact of fossil-fueled plants. A still open question is whether the required impact statement must cover the environmental effects of the plant as a whole or just the water intake structures. $^{48}$

45. Act of March 3, 1899, ch. 425, $\$ 10,30$ Stat. 1151.

46. 33 U.S.C. $\S 403$ (1970).

47. 430 F.2d 199 (5th Cir. 1970), cert. denied, 401 U.S. 910 (1971) (the Corps can act for environmental reasons rather than just reasons concerning navigation, flood control, and power production).

48. The Corps' regulations on preparation and coordination of environmental impact statements do not shed much light on the scope of the statement, although they state that: "the environmental statement is a summary of the direct and indirect environmental impacts of a proposed water resources development project or other proposal . . . ."37 Fed. Reg. 2525-26 (1972) (emphasis added).

Until passage of the Federal Water Pollution Control Act Amendments of 1972, Pub. L. No. 92-500 (Oct. 18, 1972), an additional basis for Corps authority over power plants was section 13 of the Refuse Act, Act of March 3, 1899, ch. 425, § 13, 30 Stat. 1152, which prohibits discharge into navigable waters or their tributaries of "any refuse matter of any kind or description whatever," but provides that notwithstanding this prohibition the Corps can issue permits for such discharges. Section 13 was held to apply to water pollution as well as navigational hazards, United States v. Standard Oil Co., 384 U.S. 224 (1966), thereby encompassing fossil and nuclear steam power plants, both of which discharge beated water mixed with chemicals. And a federal district court lield that a NEPA impact statement was required before a section 13 discharge permit could be issued. Kalur v. Resor, 335 F. Supp. 1 (D.D.C. 1971). The Federal Water Pollution Control Act Amendments of 1972, however, relieved the Corps of its section 13 permit responsibilities. Authority was shifted to the Environmental Protection Agency, which may further transfer it to the states. Federal Water Pollution Control Act $\S 402$, Pub. L. No. 92-500, $₹ 2$ (Oct. 18, 1972). If such a transfer occurs, preparation of a NEPA impact statement would no longer be required prior to the issuance of a permit. Thus, the only NEPA statement requirement applicable to fossil-fueled power plants, which will provide most of the electricity generated in this country for many years to come, would be the requirement grafted onto the Corps' construction permit program by Zabel v. Tabb, 430 F.2d 199 (5th Cir. 1970), cert. denied, 401 U.S. 910 (1971).

If, on the other hand, EPA retains the permit program instead of transferring it to the states, it may not have to prepare NEPA statements, since the CEQ guidelines 
Procedures under the Corps' construction permit program are informal. The permit application is filed at one of the Corps' 36 district offices, which may forward the application to headquarters in Washington. No hearings are required on the apphication, ${ }^{40}$ but a Corps decision may be challenged in federal district court under the Administrative Procedure Act. ${ }^{50}$

\section{Other Regulation}

Various types of other regulation at the state and local levels apply to utilities and their facilities, but most are unrelated to environmental protection. Twenty-nine state public utility commissions (PUC) license construction of at least some power plants, and 28 license at least soine transmission lines, but only 19 consider environmental factors in reaching their decisions. ${ }^{51}$ State PUC jurisdiction extends considerably beyond construction of new facilities, however, to review of utility rates, financial arrangements, and general adequacy of service. ${ }^{52}$ States and localities also shape utility plans through zoning and building codes, safety regulations, and planning requirements. Because coordination of regulation within each level of government or across jurisdictions is so slight, a utility's activities may be subject to conflicting requirements of several inunicipalities or agencies. ${ }^{53}$

Of major importance to utilities are air and water standards, still promulgated and adininistered chiefly by the states but subject to increasing supervision by the federal Environmental Protection Agency (EPA). Under the Clean Air Act ${ }^{54}$ the EPA Administrator must fix

exempt EPA from preparing statements when it is engaged in "environmental protective regulatory activities." 36 Fed. Reg. 7725 (1971). However, language in the new water legislation suggests that an impact statement may be required before EPA issues a discharge permit to a power plant or other pollution source on which construction starts after EPA has set performance standards:

Except for . . . the issuance of a permit under section 402 of this Act for the discharge of any pollutant by a new source as defined in section 306 of this Act, no action of the Administrator taken pursuant to this Act shall be deemed a major Federal action significantly affecting the quality of the buman environment within the ineaning of the National Environmental Policy Act of $1969 \ldots$.

Federal Water Pollution Control Act $\S 511($ c)(1), Pub. L. No. 92-500, $\S 2$ (Oct. 18, 1972).

49. 33 C.F.R. \& 209.131(k) (1972).

50. Kalur v. Resor, 335 F. Supp. 1 (D.D.C. 1971).

51. OfFice of Science and Technology, Electric Power and the EnvinonMENT 56, 57 (1970).

52. 1 A. Priest, Principles of Public Utility Regulation 32 (1969) [hereinafter cited as PRIEST].

53. See COMMITTE REPORT 118-21.

54. 42 U.S.C. $\$ \S 1857-57 l(1970)$. 
national air quality standards..$^{55}$ Then the states must produce, subject to federal approval, implementation plans adequate to achieve these standards. ${ }^{50}$ No federal review of facilities is required prior to operation, but the EPA is required to promulgate standards of performance for new stationary pollution sources. ${ }^{57}$ Under this authority EPA lias fixed performance standards for new power plants. ${ }^{58}$

The national water pollution control program was extensively revised by passage over a presidential veto of the Federal Water Pollution Control Act Amendments of 1972.59 This Act seeks to eliminate by 1985 discharge of pollutants into navigable waters. ${ }^{60}$ It empowers the EPA to fix effluent limitations for current pollution sources ${ }^{61}$ and performance standards for new pollution sources. ${ }^{62}$ The EPA may also review and override state water quality standards and enforcement ${ }^{63}$ and is authorized to establish a permit program to enforce standards set in accordance with the statute, ${ }^{64}$ but this authority may be delegated to the states. Water pollution regulation is coordinated with other federal licensing activity by the requirement that any applicant for a federal license or permit provide the licensing agency a state certificate verifying that the activity will not violate effluent limitations. ${ }^{55}$

Many other federal, state, and local requirements apply to the construction and operation of power plants and transmission lines, in addition to those outlined above, such as zoning standards, building codes, and permits for use of boilers, street openings, and the like. A single plant or line may need dozens of permits from several different jurisdictions at each level of government. Usually, these permits are routinely obtained, but a utility is always subject to uncertainty over the possibility of a veto from a town zoning board or a county highway department. ${ }^{.6}$

55. The EPA Administrator must fix both national primary air quality standards designed to protect public health, and national secondary air quality standards, designed to "protect the public welfare from any known or anticipated adverse effects" of air pollutants. $I d . \$ 1857 \mathrm{c}-4(\mathrm{~b})(1)-(2)$.

56. Id. $\$ 1857 \mathrm{c}-5$.

57. Id. $\S 1857 \mathrm{c}-6$.

58. 36 Fed. Reg. 15704-22 (1971).

59. Pub. L. No. $92-500$ (Oct. 18, 1972).

60. Federal Water Pollution Control Act $\$ 101$ (a)(1), Pub. L. No. 92-500 (Oct. 18,1972 ).

61. Id. $\S \S 301,302,307,316$.

62. Id. $\S 306$.

63. Id. $\S 303$.

64. Id. $\$ 402$.

65. Id. § 401 .

66. For a more complete discussion of these secondary requirements, see CoMMTTEE REPORT 66-67. 


\section{III.}

\section{IsSUEs AvoIDED}

The licensing procedures described in the preceding section subject each power plant and transmission line to a number of separate reviews, some going into great detail with considerable procedural forinality. The amount of review far exceeds that required for inany projects having possibly greater environmental impact such as interstate highways and petro-chemical plants.

Ironically, however, this administrative scheme avoids the most important issues concerning electric power and the environment. It focuses attention on the easier, narrow questions while assumning answers to the harder, more important ones. The administrative process asks whether a facility is needed to make supply equal denand but assumes that nothing should be done to shape the demand for power. It asks whether a plant is well designed for its type but ignores the alternative of building a different type of plant. It asks whether a plant incorporates technological advances but fails to allocate consciously the research funds that will produce toinorrow's improvements. It investigates the immediate area of a utility's proposed site in great detail but generally does not question whether the plant should be located in a different region. The fundamental issues of how much electricity slould be consumed and what sources of power should be exploited, therefore, are not resolved by conscious choice within the licensing process. Instead, they reach resolution as a random by-product of many private and public forces pursuing their disparate missions.

These gaps in the decisionmaking process exist because government structure has not adapted to changing needs and resources. The legislative committees, executive departments, and administrative agencies that specialize in energy matters took shape when few questioned nature's capacity to yield fuels and absorb waste and when government felt its role was limited to promoting energy use and regulating monopolistic practices. These governmental bodies, therefore, are generally keyed to promoting a particular form of energy. They lack the ability and motivation to analyze the overall interaction of energy, the economy, and the environment, or to weigh the comparative merits of different technologies and fuels.

The mandate of NEPA to consider these broader issues has been superimposed upon a decisionmaking structure designed for different duties. Not surprisingly, agencies with a mission to promote a particular energy source have resisted inquiring into energy conservation or the merits of different fuels. Similarly, reasonable policy alternatives have been ignored because no agency has the power to implement them. 
Thus, in spite of NEPA, the critical electricity-environment issues continue to be ignored, and their resolution by inadvertence leads to systematic mistakes.

\section{A. Demand}

The single most important issue is how much electricity society should use, but it is now resolved without conscious balancing of competing economic, environmental, and social considerations. Agencies concerned with power see as their function meeting and even encouraging growth im demand, not analyzing the consequences of growth or resource depletion. For example, utilities carry out a variety of promotional practices and offer huge discounts to large power users, thereby subsidizing growth. ${ }^{67}$ State public utility commissions review these practices only cursorily, however, and do not insist on proof of cost or on an accounting of environmental damage. ${ }^{68}$

The most important determinant of growth is price. Price affects how much today's electric equipment is used and, more importantly, affects the electrical requirements of equipment and buildings designed for tomorrow. But, the pricing mechanism artificially stimulates faster growth. Since the economy allows producers to pollute free of charge, the consumption of electricity is subsidized. Utilities have begun to spend money to reduce pollution somewhat, but the pollution that continues to take place is still cost-free. Thus, the public trust in the environment is used to stimulate faster consumption of natural resources.

While the growth rate is affected by price levels and utility promotional practices, even small changes in the growth rate would have large long-range results. The current annual growth rate of seven percent will multiply power usage between seven and eight times by the end of this century. ${ }^{69}$ Reducing the growth rate to four percent would reduce this increase to threefold.

Consumption of energy could be curbed by direct controls, such as rationing. But allocation of resources can be improved with no more governmental regulation than exists today. Government lias long controlled the level and structure of prices for electricity and other forms of energy: it sets oil import policies, gas prices, mineral depletion al-

67. For instance, Consolidated Edison's rate schedule for residential use, effective September 16, 1972, sets charges of 26 cents for each of the first ten kilowatt hours (Kwhrs), 4.9 cents for each of the next $50 \mathrm{Kwhrs,} \mathrm{with} \mathrm{further} \mathrm{reductions} \mathrm{to} 1.9$ cents per Kwhr for consumption over $360 \mathrm{Kwhrs}$. Rates go even lower for large commercial and industrial users.

68. COMMTtTeE Report 179-85; OfFice of ScIence and Technology, supra note 51 , at 47 .

69. RESOURCES FOR THE FUTURE, INC., supra note 15. 
lowances, and wholesale and retail electricity prices; and it operates the largest electric utilities and the only plants that enrich uranium. Just as the government and utilities in the past established prices that encourage consunption of energy, they could structure electricity prices to slow the growth of denand in the future. For instance, governinent could tax energy production to offset the subsidy created by costfree pollution.

Ultimately, Congress will have to set a national policy on energy consumption. But reasoned legislative decision will require substantial research and study of complicated factual matters at the administrative level. A high-level congressional study of energy policy has concluded that government currently fails to generate the data needed to understand energy questions. ${ }^{70}$ Senator Jackson has stated that, while agencies produce reams of studies,

[d]efinitions and assumptions are rarely spelled out, and the reports contain no information as to how consumption of energy and of particular fuels would be influenced by changes in prices, technology or public policy.71

The Federal Power Commission would seem to have a special obligation to help establish an informational basis for a reasoned policy on energy consumption. Congress directed the FPC to consider "conservation of natural resources" in carrying out its responsibilities, ${ }^{72}$ and the Supreme Court has instructed the FPC to weigh all alternatives, including the alternative of no plant at all, ${ }^{78}$ before granting a license. But, until recently, the FPC denied responsibility to consider power conservation or to gather the information necessary to make a conscious decision about shaping future demand. ${ }^{74}$

There are some hopeful signs, however. After considerable prodding, ${ }^{75}$ and faced with possible energy shortages, the FPC reversed its stand and issued a proposed policy statement, Electric Energy Conversion and Consumption in the Conservation of Natural Resources. ${ }^{78}$ The statement is far from satisfactory. It refuses to consider imposing linnits on consumption or consumer disincentives to yield a slower rate of growth, ${ }^{77}$ and while making a clarion call to "recognize the situation for

70. Senate Interior Committee Press Release, Aug. 1, 1972.

71. Id.

72. FPA § 202(a), 16 U.S.C. \& 824(a) (1970).

73. Udall v. FPC, 387 U.S. 428,450 (1967).

74. Interviews with FPC staff in Washington, D.C., Jan. 6, 1972.

75. See, e.g., COMMTTEE REPORT 108-09.

76. FPC, Electric Energy Conversion and Consumption Processes in the Conservation of Natural Resources-Proposed Policy Statement and Request for Comments, 37 Fed. Reg. 20045 (1972).

77. Id. at 20045: 'The Commission's basic purpose is to identify and articulate 
what it is," the statement includes no program for learning what that might be. ${ }^{78}$ Nonetheless, the FPC has at last admitted its responsibility for providing guidance on the demand issue and may someday move from form to substance by providing hard information on how the country establishes electricity output and what biases affect that process. ${ }^{79}$

\section{B. Alternatives}

How to produce electricity is an issue of considerable importance because each inode of generation has different environmental consequences. There are several basic types of driving forces available today - primarily fossil fuels, atomic fuels, and falling water. Each offers the possibility of employing quite distinct technologies and each technology has alternative refinements.

At present the choice of production mode is left to the imdividual utility, which presumably bases its selection on the cost of the various alternatives available. But these costs may bear little relation to the actual social costs of choosing one alternative over another. First, costs depend in good measure on government policies in such disparate areas as mineral depletion allowances, oil import policy, freight cliarges, sale of government-owned reserves and stockpiles, and prices charged by government-owned nuclear enrichment facilities. These policies are shaped by international and domestic political exigencies and very likely have little correlation to ecologically optimum resource allocation. Second, environmental damage is a cost not generally internalized by fuel producers or utilities; it is a social cost which is relevant in their managenent calculus only to the extent that opposition may complicate the building of a plant. Thus, there is no reason to assume that the utility's choice of production mode is socially desirable.

Yet the licensing process fails to provide effective review of the utility's choice. First, the utility must make its choice five to eight years before the plant should go on line. ${ }^{80}$ But this decision will often not re-

principles of prudent conduct which may be generally accepted on a voluntary basis ...." President Nixon's recently announced program for energy conservation is likewise voluntary. New York Times, June 30, 1973, at 1, col. 1 .

78. FPC, supra note 76, 37 Fed. Reg. at 20046.

79. Another hopeful sign comes from a staff study prepared in October of 1972 by the Office of Emergency Preparedness entitled The Potential for Energy Conservation. This is the first study by a federal agency that seriously considers steps to make a conscious choice regarding energy growth. The study is more concerned with minimizing reliance on oil imports than with reducing environmental impact, however, and does not analyze how the interaction of private and public forces produces current growth levels. Yet, it does explore the possibility of discouraging energy use through the tax laws as well as by more direct controls. Thus, there now is at least an agenda for further research and a foundation for congressional action.

80. See COMMITTEE REPORT 277-81 for a discussion of how the timing of utility decisions relates to the regulatory process. 
ceive final administrative review until several years later, when a drastic change in plans is no longer a practical possibility. Second, different federal agencies have jurisdiction over atomic, fossil, and hydroelectric generation, and each agency independently makes licensing decisions. If, for example, the AEC, after reviewing an application for a nuclear plant, decided a fossil plant would be preferable, it could not issue the appropriate license, nor would it have any assurance that the Corps of Engineers would do so. Therefore, the important issue of how to produce power is left to the utility, with its own private goals, as influenced by a variety of government actions affecting the price of fuels without conscious regard for environmental implications.

\section{Research and Development}

While the utility's choice of generation mode is important, of even greater importance is the allocation of research and developinent funds that will determine the technology available in the future. No one, however, considers what allocation of funds would produce the best results.

Historically, equipment manufacturers did the bulk of power research, ${ }^{81}$ their efforts generally concentrating on design modifications with fairly near-term marketing prospects. Then, nuclear power began a major trend towards government financing, ${ }^{82}$ which has come to encompass non-nuclear methods as well, on the theory that many innovations in the electricity field require such large sums of money and such long lead times that government involvement is required. Yet government has failed to produce any method for comparing research possibilities. Separate agencies handle different facets of energy research, thereby allowing no opportunity at the administrative level to compare, for example, the relative advantages of imvesting funds in a new atomic reactor cooling system versus a method for removing sulfur from fossil plant emissions.

Programs come together only at the White House and congressional levels, but there, officials lack the time and expertise to analyze and compare the possibilities. Moreover, since energy research is carried out by many agencies and departments, the Office of Management and Budget (OMB) claims an inability to allocate funds with any sense

81. R \& D Goals Task Force, Electric Research Council, Electric Utilities INDUSTRY REsearch AND Development Goals Through the Year 20005 (Edison Electric Institute 1971).

82. D. Rose, Rational Development of Options, at 19, papcr delivered at the annual meeting of the American Association for the Advancement of Science, Philadelphia, Pa., Dec. 28-31, 1971. 
of priorities. ${ }^{83}$ This fragmented approach to research poses the risk that the amount of funds allocated to a particular technology will depend on the power of interested corporations, agencies, and congressional committees rather than on a careful evaluation of the prospects of various research avenues.

\section{Regional Allocation}

An issue related to how to produce power is where to site new plants. The utility usually assumes that power should be generated within its own service area and proposes specific sites accordingly. Regulatory agencies carefully scrutinize proposed plant sites but generally do not question the underlying assumption that local siting is best.

There are often good reasons, however, to locate a facility outside the utility's immediate service area. Sources of air pollution should be located away from high concentrations of population; sources of thermal pollution should be sited with regard to the capacities of various water systems to absorb heat. A utility could buy power from other power systems away from its service area, but the utility's natural inclination is rather to increase its own rate base and production capacity and to purchase power only when building locally is difficult. Furthermore, the utility's choice between expansion and purchase is not easily influenced. Regulators and the public have difficulty learning whether it is practical for the utility to buy power, since purchase arrangements are concluded in private intercompany negotiations. Moreover, the Federal Power Act gives the FPC no authority to compel the sale of power in normal cases.

Some utilities now are building plants outside their states or service areas, overcoming the tendency to continue dealing with familiar local agencies. The Four Corners complex is one example; however, that site was chosen, not because it minimized environmental harm, but because it minimized public and regulatory opposition. ${ }^{84}$

\section{E. Coordination of Policy}

Electricity policy should dovetail with actions taken in regard to energy, land use, and pollution. Yet fragmented agency jurisdictions too often frustrate well-motivated policies. Therefore, what appears to be real authority to settle an issue may just be an ability to block one avenue of resolution coupled with an imability to implement the preferred program. Under the Clean Air Amendinents of $1970,{ }^{85}$ for

83. Interview with Donald E. Crabill, Chief of National Resource Prog. Div., OMB, Washington, D.C., Feb. 23, 1972.

84. See Josephy, The Murder of the Southwest, Audubon MagazINE, July, 1971, at 52 .

85. See notes $54 \& 58$ supra and accompanying text, 
example, the EPA is required to establish sulfur standards for new plant emissions and ambient air quality standards, both of which affect plants producing electricity. The EPA has sct standards that will require fossil plants to use a mixture of fuels with a much lower level of sulfur. The FPC has warned, however, that sufficient supplies of such low-sulfur fuels are unavailable. ${ }^{86}$ Steps could have been taken to increase supplies to meet EPA standards, but neither EPA nor the FPC has the power to initiate such steps.

The lack of focus in the regulatory process leaves the most critical aspects of electricity and the environment to the random interaction of public and private forces pursuing their own narrow missions. Resolution of crucial social issues is thus an unconscious by-product of selfinterested activity biased in favor of fast growth, inexpensive but highly polluting production modes, nuclear research, and plant siting in regions of high population concentration.

The purpose of NEPA was to make agencies consciously resolve issues affecting the environment and to avoid past mistakes caused by ignoring the broad inplications of isolated day-to-day decisions. ${ }^{87}$ NEPA told agencies to report to Congress instances where their statutory authority was too limited to respond adequately to a broad set of alternatives. Agencies concerned with electricity and the environment uniformly rephed, however, that their present powers were sufficicnt to carry out the purposes of NEPA. ${ }^{88}$ The extent to which broad issues are now avoided indicates the agencies have no desire to wield the authority necessary to iniplement NEPA.

NEPA commands that agencies consider the merits of a broad range of alternatives, but agencies often lack the authority to implement plausible alternatives. The Court of Appeals for the D.C. Circuit has confronted this problem in Natural Resources Defense Council $v$. Morton. ${ }^{89}$ The Secretary of Interior had refused to consider as an alternative to granting off-shore oil leases the use of other sources of energy on the ground that he lacked authority to carry out such alternatives. The court held that the Secretary must consider all reasonable alternatives because NEPA statements provide guidance to Congress and other decisionmakers that do have broader powers. ${ }^{90}$

86. 1 FPC, The 1970 National Power SURvey I-1-20 (1971).

87. "Important decisions concerning the use and shape of man's future environment continue to be made in small but steady increments which perpetuate rather than avoid the recognized mistakes of previous decades." S. REP. No. 296, 91st Cong., 1st Sess., at 5 (1969).

88. See Committee Report 113.

89. Natural Resources Defense Council v. Morton, 458 F.2d 827 (D.C. Cir. 1972).

90. Id. at 834 . 
This decision does not cure the problem of agency structure frustrating the immediate purposes of NEPA. But it at least thrusts into view the need to realign administrative structure to comport with the critical issues of the future. Similar interpretations of NEPA in the area of electric power and the environment should hasten the reform of administrative decisionmaking to provide bodies with the authority and expertise necessary to consider presently avoided issues while options are still open.

IV.

\section{Public Decisions Made in Private}

While the decisionmaking process has many shortcomings, licensing does purport to review such important issues as a facility's specific site, safety, and levels of emissions to the air and water. In theory, this review takes the form of an application, a public learing, and a reasoned decision on the record. In practice, however, most issues are resolved in private negotiations even before an application is filed. Since the utility and the agency have reached an agreement before the proposed facility is revealed to the public, the hearing process becomes a hollow ritual with the agency and the utility defending their bargain. Even when intervenors offer a contest, the agency almost invariably sticks by its bargain with the applicant.

While the flexibility of bargaining may aid formal adjudication when coinplex scientific issues are involved, the licensing agency's relationship to industry, its developmental orientation, its usually inadequate staffing, and its willingness to negotiate in private make it a poor bargainer. Moreover, both sides have an incentive to protect their bargain by denying potential intervenors the information necessary to argue the issues. The net results are poor decisions, public distrust, increasingly frequent intervention, judicial reversals, and unnecessary delay.

Industry and government need to communicate with eacli other, particularly about the development of new technologies. Even discussions regarding regulatory activities serve to help industry prepare better applications and avoid wasting inoney and time on unacceptable designs. But these functions can be served without private discussions on the merits.

\section{A. The Bargaining Process}

Ex parte meetings of industry and agency staff take place both in standing industry-agency committees concerned with broad-based issues and in negotiations involving applications for specific facilities. 


\section{Industry-Agency Committees}

The number of joint councils or committees with both industry and regulatory meinbers has grown, but few if any have outside interests represented. This trend deinonstrates a blurring of public and private roles which carries with it the danger that a standing committee will usurp a commission's ultimate decisionmaking authority. According to the AEC's Director of Regulation, for instance, 46 separate utility-commission committees exist to formulate codes and standards for the safety of nuclear facilities. ${ }^{.1}$ A manager in the AEC's Division of Reactor Licensing can recall no case where an aspect of an application founded on the recommendation of one of the councils was ultimately overturned by the AEC regulatory staff. ${ }^{22}$ The AEC is now calling for industry to take an even more active role in setting nuclear safety standards..$^{93}$

Other agencies have similar industry-agency committees. The FPC's advisory committees, which work on growth projections and power surveys, are chaired and dominated by utility officials. ${ }^{04}$ In response to criticism, the FPC has recently begun to include outside interests, but in a form bound to minimize their impact. The Commission set up an advisory committee and three subsidiary task forces to consider growth in energy consumption. ${ }^{55}$ But while a few environmentalists were appointed, they were segregated in a task force dealing with environmental factors and kept off the task forces dealing with actual practices. The net result is likely to be a report with some nice language on environmental considerations and a set of reconumendations for business as usual.

Even more worrisome are the three $\mathrm{OMB}$ advisory committees dealing with public utilities. ${ }^{96}$ The committees' stated task is to help the OMB oversee information-gathering by federal agencies. ${ }^{97} \mathrm{OMB}$ claims that its right of intervention does not extend to the regulatory decisions of administrative agencies. Nonetheless, the OMB has chosen to review the AEC's guide for the preparation of environmental reports. Moreover, even though top officials of the Environmental Protection Agency claim to make the final decisions about the administra-

91. Remarks of L.M. Muntzing, in A Standard for Evaluation of Licensing Applications-Quality In, Quality Out, 2 AEC NEws RelEases No. 47, at 16 (1971).

92. Interview, Bethesda, Md., Jan. 8, 1972.

93. See, e.g, Remarks by AEC Commissioner William O. Doub, Reflections After Fifteen Months, 3 AEC News RelEASES No. 50, at 8 (1972).

94. Statement of J.N. Nassikas, Chairman, FPC, Hearings on S. 3067 Before the Subcomm. on Intergovernmental Relations of the Senate Comm. on Government Operations, 91st Cong., 2nd Sess., pt. 3, at 508 et seq. (1970).

95. 37 Fed. Reg. 26639-42 (1972).

96. Hearings on $S$. 3067, supra note 94, pt. 1, at 131-32.

97. 44 U.S.C. $\$ \$ 3501-11(1970)$. 
tion of the Clean Air Act, staffers will admit privately that $O M B$ and White House officials must approve the final decisions. Industry appears to agree with the staffers' view of OMB's power. ${ }^{98}$ Thus, after all sides make their arguments to an administrative agency and the agency makes its decision, industry has exclusive access to a private administrative appeal to $\mathrm{OMB}$ whose advisory committees consist solely of utility representatives and $O M B$ officials. A hopeful note, however, is that Congress has required the Consumer Product Safety Commission to subinit its budget requests and legislative recommendations directly to Congress without prior $\mathrm{OMB}$ or White House approval..$^{99}$

AEC, FPC, and OMB committees, as well as those of other agencies, deal with both public and private issues. Their impact on ultimate regulatory decisions is unclear, and whether they involve an unlawful delegation of governmental authority is difficult to assess. At the least, the public's ability to influence decisions and review the decisionmaking process should be strengthened by requiring equal representation on these panels for interests adverse to industry and by requiring that summaries of all discussions and conclusions be published.

\section{Industry-Agency Negotiations}

In addition to working together on the various joint bodies which influence general regulatory policy, utilities and agencies negotiate regarding specific facilities, usually before a formal application is filed. By the time an application receives a public liearing, a bargain has been struck on all major issues. While the unwritten procedures of all the important agencies allow pre-hearing negotiation, the AEC has the most developed system. ${ }^{100}$ Even before the utility has finalized plant designs, numerous efforts are made to agree on issues privately. Equipinent designers, architect-designers, and the utility representatives discuss with the AEC regulatory staff such issues as hardware specifications, design, and siting, usually receiving informal staff assurances that particular choices are acceptable.

Once the architect-designer files a detailed application on behalf of a utility, conferences begin, usually lasting about two years. The agency staff surveys the plant design in some detail; when problems are found, compromises are negotiated. Then, the Director of Regn-

98. Commenting on industry's plea to OMB to revise the AEC's guide for the preparation of environmental reports, one industry source reportedly said: "This is really going to blow the top off the AEC." NuCLEONICs WeEK, Aug. 3, 1972, at 1.

99. Pub. L. No. 92-573, §§ 27(k)(1), (2), 86 Stat. 1207 (Oct. 27, 1972).

100. The summary of AEC bargaining procedures that follows is derived from a series of interviews with meinbers of the AEC regulatory staff and is analyzed in more detail in COMMITTEE REPORT 70-72, 146-49. 
lation issues a preliminary safety analysis review, an environmental statement, and a letter indicating staff approval. While the regulatory staff is evaluating the application, the Advisory Committee on Reactor Safeguards, a statutory body of scientists that must pass on all plants, also holds conferences with the regulatory staff and the applicant's representatives. Until only a few months ago, outside observers were not allowed to participate. Under the pressure of recent federal legislation, however, some public participation in ACRS proceedings and access to ACRS documents have been permitted, but the extent of this access is not yet clear..$^{100 \mathrm{a}}$

Similarly, potential hydroelectric project developers consult extensively with the FPC before any forinal application triggering public notice is filed. ${ }^{101}$ The FPC prepares river basin studies to locate potential hydro sites, and these studies often serve as the basis for inforinal applicant-staff discussions. The FPC may also issue "no action" letters to potential developers assuring them that preliminary work at sites will not disadvantage thein.

Agency-imdustry negotiations need not be secret, however. When one utility attempted to include the public in selecting a plant site, the results were positive. In 1970, Northern States Power Company (NSP) invited members of every environmental organization in Minnesota to participate in the selection of a new plant site. Initial ineetings of the group thus assembled were rather storiny, but group members eventually agreed to work with the utility and picked one of four possible sites proposed by NSP. NSP accepted the group's choice although it had not favored the site initially. When NSP applied to the state for a permit to build the plant, there was no public opposition whatsoever and approval was prompt. The public planning group did not disband following this one site selection. It continues to meet to consider possible future sites as well as issues raised by the continuing growth of demand for power. At the group's suggestion, NSP has halted all product advertising and is dismantling its marketing efforts. ${ }^{102}$

The apparent success of the approach used by NSP may have prompted one utility group, the Environmental Committee of the Western Systems Coordinating Council, to recommend recently that utilities in siting new plants:

encourage advance local participation and public planning discussions in the area to be affected by the proposed facilities as a means

100a. See NuCLEONICS WEER, note 24 supra.

101. Interviews with FPC staff, Washington, D.C., Jan. 6, 1972.

102. The NSP experiment is described in National Academy of Enginezring, ENGINEERING FOR RESOLUTION OF THE ENERGY-ENVIRONMENT DILEMMA 307.09 (1972). 
of resolving conflicts in advance and achieving a rational balance between electric reliability and a quality environment. ${ }^{103}$

\section{B. The Predetermined Conclusions of Public Hearings}

Because of the important role of industry-agency committees and the practice of lengthy applicant-commission bargaining, rarely does an application reach hearing without the applicant feeling fairly confident the license will issue. This confidence has solid foundation in experience. There is no case on record of the AEC's denying an application to construct or operate a nuclear power reactor after it has reached the hearing stage. Similarly, during its 50 years of operation the FPC has denied for environniental reasons only two applications to construct a hydroelectric plant. ${ }^{104}$ And, no case is known of the Corps of Engineers' refusing to grant a construction permit for a fossil-fueled power plant. Indeed, until 1972, the Corps had not considered any application to be sufficiently important to refer to its Washington office. ${ }^{105}$ The record at the state level is similar, with few cases of applications being denied after hearing. ${ }^{106}$

Applicant and agency views coincide at the hearing stage not only on whether the license should be granted, but also on the significant conditions to be attached. This absence of conflict at the hearing between the utility and the agency undercuts the evidence-testing function of the adversary process; and because intervenors lack information and resources, they can only infrequently and partially do the agency's job of subjecting the applicant's case to critical public examination. ${ }^{107}$ One notable exception to this pattern recently occurred when Consolidated Edison applied for an operating license for its Indian Point II plant. ${ }^{108}$ At the urging of intcrvenors, the AEC's staff concluded that the plant should be licensed, but only on condition that the utility build and use cooling towers to save the chief spawning ground of the Atlantic Coast striped bass population. The utility lias decided to contest this proviso, thereby creating what inay be the first public conflict between an applicant and the AEC staff.

103. Western Systems Coordinating Councin, Environment Committee, EnVIRONMENTAL GUIDELINES 3 (1971).

104. Namekagon Hydro Co. v. FPC, 216 F.2d 509 (7th Cir. 1954), and Public Utility Dist. No. 1 of Skamania County, Washington, Project No. 2199, 32 F.P.C. 444 (1964).

105. Interview with Corps of Engineers staff, Washington, D.C., Jan. 6, 1972.

106. COMMTTEE REPORT 146.

107. Public Particiation in Administrative Hearings, 1971-72 ADMIN. CONFERENCE of THE U.S. REP. 59 (recommendation 28 to the Administrative Conference of the United States).

108. The Indian Point II plant is operated by Consolidated Edison Co. in Buchanan, New York on the Hudson River. 
The usual lack of public conflict does not mean that the whole licensing process is necessarily a rubber stamp. Agency pressure does result in applications being modified or withdrawn before hearing. But negotiations jeopardize the very purpose of the hearings. The agency is called upon to judge a bargain to which it has agreed at a time when changes would be expensive, if not impossible, chiefly because so much time was spent in private negotiations. ${ }^{100}$

Moreover, by the time of the public hearing the utility has already bought land, ordered equipinent, and invested in plant design in reliance on inforinal agency approval. At this stage, vested interests in the application can be huge. ${ }^{110}$ In one recent case, a utility seeking to construct a nuclear power plant reported having spent $\$ 48$ million before the hearing, $\$ 12$ million of which would be unrecoverable if a license were denied. Since the reactor vessel itself was 50 percent coinpleted, the AEC could not order substantial changes in design without great economic loss. Furthermore, the reactor vessel had not yet been inspected by the AEC so that some faults would be hard to detect and others niore costly to correct than if found earlier. ${ }^{111}$

The closed bargaining process, therefore, makes it likely that public hearings will be no more than foregone conclusions. Indeed, if this were not the case, the process would expose ratepayers to the needless risk of losing millions of dollars should an adverse decision ultimately be rendered.

\section{Are the Agencies Good Negotiators?}

Industry and agency personnel share intervenors' low opinion of the present hearing process, but for different reasons. Intervenors view hearings as public relations gimmicks to legitimize behind-thescene deals; they want hearings where projects are inore closely scrutinized. Industry and agencies see hearings as a discipline on hard, arms-length negotiation between agency and applicant; they want hearings that end quickly unless intervenors can show major substantive

109. B. Boyer, A Re-evaluation of Administrative Trial-Type Hearings for Resolving Complex Scientific and Economic Issues, at 27-28 (1971) (a staff report to the Administrative Conference of the United States):

Agency projects gather momentum as time, effort and capital are invested in them-even if the only investment has been analytical time .... [t]here will be strong pressure to persist with the original plan if the superior plan later becomes apparent.

This report appeared in modified form as Boyer, Alternatives to Administrative TrialType Hearings for Resolving Complex Scientific, Economic, and Social Issues, 71 Mrcr. L. REV. 111 (1972).

110. Noll, The Economics and Politics of Regulation, 57 VA. L. REv. 1016, 1022 (1971).

111. Mosby, AEC Rates N-plant Construction Sound, Bay City (Mich.) Times, July 22,1972 , at $1 \mathrm{~A}$, col. 4 . 
flaws in the application. If one takes these claims at face value, the difference in position inay be explained by disagreeinent as to the efficacy of the bargaining process.

An outside observer has trouble judging the substance of the bargains inade, particularly since negotiations are secret and each application is coinplex. Yet agency structure, agency staffing, and extraagency influence all inake it doubtful that negotiations will produce sound results.

\section{Agency Structure}

Effective bargaining requires adverse bargainers working toward a coinpromise position. If all interests are represented, the result might approximate the "public interest." In license bargaining, however, the utility represents one adverse position; the agency theoretically represents the middle ground of the "public interest"; but no one represents specific consumer and environmental interests. Thus, the negotiations begin out of balance.

A close look at agency structure calls into question whether the agencies can fairly represent even a coinpromise position. This is their mandate as regulators. But Congress has also assigned agencies sucl1 as the AEC and the FPC developinental duties-to proinote technologies and new construction. Agencies may therefore become blind or imdifferent to non-developinental alternatives. A report to the Chairman of the Administrative Conference of the United States, for exainple, recognized that "subtle forns of bias can result from agency structure"112 and that

bodies like the Army Corps of Engineers which are essentially "construction agencies" may tend to favor structural alternatives when confronted with a problem. ${ }^{113}$

Not only must administrative agencies fulfill the incoinpatible roles of proinoter and regulator, they inust assume other conflicting taskscounseling and advising applicants and then impartially judging the applications they helped develop. As Florida's Governor Reubin Askew said of his state public utility commission:

I submit that we have assigned too many difficult roles to the commission and its staff together. We have asked them to function not only as judge and jury, but as imvestigator, prosecutor, defense attorney, and enforcer as well. It is obvious that these roles are incompatible. ${ }^{114}$

112. Boyer, supra note 109 , at 8.

113. Id.

114. Address by Gov. Reubin Askew to the Florida Assembly, Feb. 1, 1972. 


\section{Staffing}

Of the commissions concerned with plant licensing, the AEC and the FPC appear to have the best staffing patterns. Even they, however, lack sufficient staff to process applications with speed and thoroughness, and their requests for more personnel have lagged behind the growth of their environmental duties. ${ }^{116}$ By contrast, other agencies concerned with facility licensing liave the most meager of resources, insufficient to deal with complex issues let alone negotiate effectively with applicants for licenses.

Although the Corps of Engineers has now lost its Refuse Act permit program to the Environmental Protection Agency, ${ }^{110}$ it still administers the construction permit program, under which it must handle navigational, environmental, and other issues, and prepare NEPA statements. To deal with this large and complex program, which provides the only environmental review for fossil-fueled power plants, the Corps einploys at the district office level 174 people full-time and half that number part-time. Almost all are clerical personnel, with no training in the relevant disciplines. At the national level, the staff consists of five engineers and three clerical people. ${ }^{117}$ Such a staff is barely sufficient to process the construction permit papers and hardly adequate to negotiate with applicants or to carry out the inter-disciphinary costbenefit analyses required by NEPA.

The responsibilities of state public utility commissions are often even more complex than those of federal administrative agencies. They must supervise rates, capital structure, service, safety, and often environmental impact of utilities providing power, gas, coinununications, water, and transportation. But they are generally staffed less adequately than federal agencies. Over two-thirds of the commissions have five or fewer engineers, and in 1967 all the commissions had a total of only seven geologists. ${ }^{118}$ Almost one-fifth of the states scrimp by with parttime coinmissioners, and half of the rest pay their chairman no more than $\$ 20,000{ }^{119}$ In 1967 four-fifths paid their chief of staff $\$ 15,000$ or less. $^{120}$ The staffing of state pollution cominissions is even less ade-

115. See, e.g., Comptroller General, Management Improvements NeEded in the Review and Evaluatron of Applications to Construct and Operate Nuclear Power Plants, at 4, 63 (GAO B-127945, 1972).

116. See note 48 supra.

117. Interview with Corps of Engineers staff, Washington, D.C., Jan. 6, 1972.

118. Subcomm. on Intergovernmental Relations of the Senate Comm. on Government Operations, State Utility Commissions, S. Doc. No. 56, 90th Cong., 1st Sess., at 7 (1967).

119. Letter from Paul Rodgers, Nat'1 Assoc. of Reg. Comm'rs, Jan. 1, 1972.

120. SubComm. on Intergovernmental Relations, supra note 118 , at $7,9$. 
quate. Only nine states had agencies with full-time commissioners in 1971. The rest sought to protect their air and water with boards coinposed of part-time citizen members. ${ }^{121}$

\section{Outside Influence}

Agency staff at all levels are under subtle pressures that can undermine their neutrality. Middle-level civil service employees must nake decisions during the bargaining process that may have inulti-milliondollar consequences for large utilities and giant equipment manufacturers. Since these companies and their lawyers can get at least an audience at high levels, employees might be apprehensive of writing reports that might damage their opportunities for advancement. There are many dedicated engineers and scientists at the AEC, for example, who take to heart their responsibility for licensing nuclear plants, and it seems unlikely they would consciously decide for a utility-applicant in a situation where substantial danger was involved unless they believed such a decision was justified by the facts. Yet many decisions involve trading-off huge costs against a slight reduction in the miniscule risk of a huge disaster, and inost issues are clouded by scientific uncertainty. Not only do conflicts between staff and applicant rarely involve clean-cut issues, but standards for decisionmaking are far froin clear, and outcomes may depend on unconscious bias. As a report to the Administrative Conference noted, the complex issues involved in licensing

exacerbate the risk of partiality, because of the nebulous standards of decision, very limited role of stare decisis and potentially large numbers of interests affected-nany of them possessed by non-parties, who may well be teinpted to employ extra-record influence. ${ }^{122}$

One example of imdustry's influence on regulatory procedures is found in a little-publicized report by the General Accounting Office, which strongly condemns the AEC's practice of cutting short safety reviews in order to meet applicants' schedules. It cites interviews with two of four project leaders who admitted they curtailed review efforts because of applicants' desires to meet scheduled construction or operation dates. ${ }^{123}$ Yet the Director of the Division of Reactor Licensing demied that such accommodations interfere with the agency's ability to ensure safety. ${ }^{124}$

121. Hill, States Curtailing Polluters on Pollution Control Units, N.Y. Times, Dec. $19,1971, \S 1$, at 1 , col. 3 .

122. Boyer, supra note 109 , at 8.

123. COMPTROLLER GENERAx, supra note 115 , at 30-31.

124. Id. The Director's rather confusing denial was that:

[S]cheduling, assignment of priorities, and decisions on depths of reviews were 
One possible avenue for extra-record influence is through the commissioners and top staff of the various agencies. They spend much more time talking with industry representatives than with environmentalists or consumer groups, as would be shown by scanning the list of groups addressed and conferences attended by a typical commissioner. ${ }^{125}$ Other possible sources of influence are Congress, the Office of Management and Budget, and the White House itself.

With outside influence, poor staffing, and conflicting roles all undercutting an agency's ability to bargain effectively, private negotiations cannot be depended upon to yield decisions in the public interest. Public hearings should, in theory, rectify the situation. But a hearing becomes just a formality when the agency and applicant both have an interest in defending a previous bargain.

Intervenors have tried to introduce new points of view at the hearing level, and courts have told commissions they should welcome this added source of information. ${ }^{126}$ Yet simce the coinmission is a party to the bargain, it more naturally perceives imtervenors as an attacking enemy than a helping hand. Since the agency's expenditure of time and money makes rescinding the bargain at the hearing stage costly, the agency as well as the utility has a strong incentive to discourage participation by the public. This can be effectively accomplished by denying information to the public and making intervention mconvenient and expensive. These are the subjects of the next two sections.

V.

\section{LACK OF DISCLOSURE}

Disclosure of information necessarily precedes effective public participation and debate. With scientific innovations so frequently overrunning an understanding of their consequences, a free flow of information is critical to the quality of administrative decisionnaking. Yet the present decisionmaking structure discourages information flow and open discussion. The issues avoided, often falling outside any agency's

management functions and that, when decisions had been made to curtail the depths of reviews, such decisons did not imply any lack in the scopes or depths of reviews necessary to ensure safety.

125. James Landis, in a report to President-elect Kennedy, warned of the unconscious effect of such continual contact and lobbying:

It is the daily machine-gun like impact on both agency and its staff of industry that makes for industry orientation on the part of many honest and capable members as well as agency staffs.

J. Landis, Chatrman of Senate Subcomm. on Administrative Practice and ProCEDURE TO THE COMM. ON THE JUdiciary, 86Th CONG., 2D SESS., REPORT ON REGULAtory Agencies to the President-Elect 71 (comm. print 1960).

126. See, e.g., Scenic Hudson Preservation Conf. v. FPC, 354 F.2d 608 (2d Cir. 1965), cert. denied, 384 U.S. 941 (1966). 
jurisdiction, are rarely the subject of data gathering. To the extent that industry-agency committees and private negotiations supplant hearings, even less information gets to the public. But the bigger share of the blame belongs to the informational policies of industry and government agencies.

The difficulties outsiders often encounter in getting information from the utilities and their regulators were illustrated several times during the preparation of the report of the Special Committee on Electric Power and the Environment. ${ }^{127}$ For example, the Edison Electric Institute (EEI), a inajor utility trade association, made two studies to discover what factors delayed the opening of new power plants. However, repeated requests to EEI for copies of the studies, which were discussed in congressional liearings, got no response, perliaps because of the studies' conclusion that environmental opposition was of minor importance in slowing new plants.

During early 1972, the AEC undertook a major reorganization of its operating division based on a report by the consulting firm of Arthur D. Little, Inc. The Special Committee requested a copy of the Little report. Only after the intervention of AEC Commissioner William Doub was one staff member from the Special Committee permitted to see the Little report at the AEC, in the presence of the Assistant General Manager of the AEC. Note-taking was forbidden, and access was granted on the express condition that no inaterial from the Little report be used in the Special Committee's report. The reason given for such extreme caution was possible embarrassment to individuals named in the Little report. However, no individual was named in the report; rather, it contained useful criticisms of the operation and organization of the AEC and its divisions.

Another study of delays in opening new nuclear power plants was conducted by the AEC's Office of Planning and Analysis. Reportedly, the study showed that environmental opposition was not a significant source of delay. A request to the AEC for the study resulted in a decision by the full Commission not to release the report until it had been "refined," a process which would require "several months" since it was being put on a "back-burner." An industry weekly reported that the Office of Planning and Analysis was "refining its methodology because of the study's 'somewhat unexpected results." "128 Perhaps incidentally, shortly after the Commission refused to release the study, Congress passed legislation requested by the AEC on an emergency

127. See note 1 supra.

128. Nucleonics WeEk, Sept. 28,1972 , at 1. 
basis to authorize AEC licensing of nuclear plants without the full NEPA review required by Calvert Cliffs Coordinating Commission v. AEC, on the theory that such complete environmental review was significantly delaying plant construction. ${ }^{129}$

Also aimed at einergency licensing legislation was a February, 1972 report prepared by the National Electric Reliability Council (NERC), which warned of a possibly "disastrous" power shortage during the summer of 1972 if several new plants were not promptly licensed. The NERC report was not, however, released to the general public and a request by the Special Committee for a copy was not answered. Ratlier, the report was quickly circulated to government officials in Washington, reportedly

because some industry officials felt their immediate objectives-getting legislation to overcome nuclear delays and an executive directive to overcome fossil delays-could be better achieved by restricting circulation of the report to government channels for the time being ... [An] industry source asked: "What's to be gained? We already have it [the report] before the people who should be most able to help us." "130

A final illustration is furnished by the pattern of distribution of Part I of the FPC's 1970 National Power Survey. Part I, which contained the Commission's own conclusions and recommendations "for growth of the electric power industry," as well as a great deal of background data, was released April 15, 1972. Copies were mailed free of charge to all electric utilities in the country, all members of Congress, all state commissions, and all members of the FPC's advisory committees. Requests directed to the FPC's Office of Public Information revealed that the general public could secure a copy only by (1) going in person to the FPC in Washington and buying it, or (2) ordering the docunent by inail from the Government Printing Office, in which case delivery would take several months. The Special Committee was only able to get a copy in time for use in preparing its report by special request to the FPC's general counsel.

The Special Committee eventually received access to nost of the reports and other sources of information that came to its attention. But

129. See text accompanying note 33 supra. Calvert Cliffs held that the AEC must comply with the procedural directions of NEPA "to the fullest extent possible." Calvert Cliffs Coordinating Coinm. v. AEC, 449 F.2d 1109, 1115 (D.C. Cir. 1970).

130. Electrical WEEK, March 6, 1972, at 2. The report was subsequently put into the record of a congressional hearing, but only portions were included in the printed record. It was the publisher of Electrical Week, incidentally, which former FPC Commissioner Charles Ross had to threaten with suit in order to secure a subscription to Electrical World, another trade publication, ouce he left the FPC and began a consulting firn in Vermont, unaffiliated with the utility industry. 
this partial success was undoubtedly due at least in part to the connections the majority of its inembers enjoyed with the utility industry or industry regulators. For a member of the general public or an environmental organization, the task would have been much more difficult, if not impossible.

This tendency to suppress information has been criticized by at least one court, which scolded the FPC for forcing intervenors to go to court to compel disclosures under the Freedom of Information Act. ${ }^{131}$ The AEC, the energy agency with perhaps the best record, has been scored for similar reasons. Forbes Magazine reported that the AEC has spent $\$ 50$ billion over the past three decades with less public knowledge or scrutiny of its activities than any other administrative agency, save the Central Intelligence Agency:

Operating in secrecy, it could fend off the occasional critics of its nuclear power programs by referring cryptically to its military and national policy responsibilities. It has developed a dedicated group of supporters, lobbyists and vested interests both within and without the AEC, who yield hittle to the infamous Highway Lobby in their stubborn conviction that theirs is the ouly right way. ${ }^{132}$

The AEC's attitude toward the flow of information is particularly important since almost all experts in nuclear safety matters work either for the AEC or its contractors. But during a recent AEC liearing on an important safety issue, a top official of an AEC contractor testified that there is both "inhibition of frank and free discussion"133 and censoring of reports by the AEC's Division of Reactor Development and Technology. The division director conceded that reports are carefully "reviewed," with the scientific results of reports prepared by employees of AEC contractors, he "cracks down" on the dissidents" employers. ${ }^{135}$

Such a policy would seem to raise first amendment questions. In any event, it certainly ignores Congress' mandate to the AEC that the dissemination of information should be encouraged "so as to provide that free interchange of ideas and criticism which is essential to ...

131. Greene County Planning Bd. v. FPC, 455 F.2d 412, 417 n.12 (2d Cir.), cert. denied, 409 U.S. 849 (1972).

132. Atoms and Dollars, Forbes, Oct. 1, 1971, at 24.

133. Testimony of Curtis Haire, manager of nuclear safety programs for Aerojet Nuclear Corp., at AEC hearings on the emergency core cooling system, quoted in NuCLEONICS WEEK, April 13, 1972, at 4.

134. The director replied: "Censoring? If you want to use this teruninology in the sense that I think you are using it, yes, we are reviewing. We are attempting to get management there to review these reports better." Id.

135. Interview with Milton Shaw, Germantown, Md., Jan. 6, 1972. Mr. Shaw is resigning, apparently under pressure froin the new AEC Chairwoman, Dr. Dixy Lee Ray. N.Y. Times, June 15, 1973, at 13, col. 1. 
progress and public understanding." 130 The AEC denies the existence of such practices; ${ }^{137}$ nonetheless, the basic motivation to suppress adverse information is inherent in a developmental organization, particularly one so closely linked to industry.

While one may fault agency personnel for specific actions, the final test should be the more functional one of whether the critical issues actually reach the public. One example concerns the AEC's fast-breeder reactor program. The fast-breeder reactor differs from today's uranium-fueled reactors in that it uses plutonium as a fuel and "breeds" more fuel than it consumes, thereby stretching almost infinitely the dwindling supplies of cheap atomic fuel. ${ }^{138}$ To take advantage of these economies, President Nixon has announced the construction of two fast-breeder prototype plants in furtherance of the AEC's goal of having several liundred such plants in commercial operation by the end of the century. ${ }^{139}$

Yet the fast-breeder presents several special safety problems, one of which is "plutonium diversion." Unlike the uranium fuel currently used in reactors, plutonium can be turned into an atomic bomb without great skill and expensive equipment. According to Science magazine, the World Book Encyclopedia provides all the information necessary. The quantity of plutonium needed is mimiscule-no more than 15 pounds. In contrast, a single shipment to a single prototype fastbreeder plant will imvolve several tons. ${ }^{140}$

No doubt the AEC will require utilities to invoke stringent security measures. Yet the incentives to steal plutonium are so great and the opportunities for theft so many, that adequate protection may be quite difficult. The theft of part of a shipment of plutonium could turn a small, perhaps desperate, nation into a nuclear power or allow a lunatic to rivet world attention as no hijacker ever has. A blackmailer might cache a shipment and dare the government to guess whether he had made the plutonium into a bomb. With these incentives, people might go to great lengths to get plutonium, paying huge suuns to organized crime or forming a raiding party themselves. Employees of utilities or processors storing plutonium could steal one or more tiny pellets a day

136. AEA § 141, 42 U.S.C. § 2161 (1970).

137. See, e.g., statements attributed to AEC Chairman James Schlesinger, NoCLEONICS WEER, March 23, 1972, at 3.

138. See AEC, Environmental Statement on the Liquid Metal Fast Breeder Reaction Demonstration Plant 5 (Wash.-1509, April, 1972).

139. President Nixon, Energy Message, June 4, 1971; Speech by President Nixon, Hanford, Wash., Sept. 26, 1971; Speech by AEC Commissioner Doub, 2 AEC NEws Releases, No. 50, at 7 (Dec. 15, 1971).

140. Shapley, Plutonium: Reactor Proliferation Threatens a Nuclear Black Market, SCIENCE, April 9, 1971, at 143. 
so that in a few months they would have enough to make a boinb. Measurement techniques are sufficiently imprecise that authorities would have difficulty determining whether a blackmailer making such a claim was bluffing.

One AEC Commissioner has termed the diversion of plutonium as "likely" and leading to a "black market."141 To counter this possibility, authorities will eventually have to guard the projected several dozen multi-ton shipments to be made each day, as well as the plutonium warehoused in hundreds of plants across the country. The problem will be compounded by the bomb-material being held by hundreds of different private corporations.

Many uncertainties surround the likelihood and future imphications of plutomiun diversion. Of striking importance, however, is that the public has never received information adequate to permit an informed discussion of this problem. A thorough survey of the AEC's literature on diversion shows practically complete silence on the issue. And AEC documents on the fast-breeder, as well as speeches by President Nixon and the Commissioners of the AEC, lave contained virtually no discussion of the risks posed by plutonium diversion. ${ }^{142}$ Thus, a diligent citizen or congressman could read a wide range of government documents on the fast-breeder and not know that bombs can be made from its fuel. In the

141. Id.

142. Consider the treatment of the issue in the following speeches and documents:

(1) President Nixon's Two Statements: No mention of diversion or plutonium's bomb potential. Address by R. Nixon, Washington, D.C., June 4, 1971; Address by R. Nixon, Hanford, Washington, Sept. 26, 1971.

(2) AEC Commissioners' Speeches: No mention of plutomiun's bomb potential, although two speeches note briefly that plutonium is dangerous.

(3) AEC's Cost Benefit Analysis: No mention of bomb potential or diversion, even in a hundred-page document with sections entitled "Other Considerations" and "Major Assumptions." AEC, Cost-Benefit Analysis of the U.S. Breeder Reactor Program (Wash.-1126, April, 1969).

(4) AEC's First NEPA Statement: In this 88-page statement issued after the decision to proceed, there is one paragraph starting, "An inherent problem in the use of plutomium as fuel for nuclear reactors is that of the potential for diversion of this material to unauthorized uses." The paragraph goes on to assert without detail the existence of safeguards, but does not even mention that "unauthorized uses" might include bombs. AEC, Enviroumental Statement on the Liquid Metal Fast Breeder Demonstration Plant 50-51 (draft 1971).

(5) AEC's Second Draft NEPA Statement: This several-hundred page document is even less clear on the possibility of diversion, but does recite the outline of the AEC's program to measure quantities of plutonium-that is, to discover thefts after the fact. AEC, Environmental Statemeut on the Liquid Metal Fast Breeder Demonstratiou Plant 92-98 (Wash.-1509, April, 1972).

(6) AEC's Understanding the Atom Series: None of the titles in this series designed to keep the public informed contains any mention of plutonium diversion or plutonium fuel's boneb potential.

The speeches and documents are listed in more detail in COMMrTtee RePORT 135 n.153. 
few cases where diversion is mentioned, one would already have to be aware of the potential risks to understand the reference. This is not a case where the government lacks relevant information. The AEC has many unclassified low-visibility studies available on request; ${ }^{143}$ it simply decided not to incorporate any of this material into the breeder literature disseminated for public consumption.

The treatment of the diversion issue exeinplifies, not complete suppression of information, but its handling in such a way that a conscientious official or voter would have the least chance of knowing of its existence. This highlights one of the problems of relying on the Freedom of Information Act alone, because its operation requires that people know enough to recognize a relevant issue and request an identifiable document. ${ }^{144}$

The AEC, however, has a clear duty to call this issue to the pubhic's attention. One of the inain purposes of NEPA was to expose such important issues. Moreover, Congress established as part of the Atonic Energy Act a policy of providing information so as to encourage debate and criticisin. ${ }^{145}$ In fact, AEC Commissioners theinselves talk of the need for full, frank discussion. ${ }^{146}$ Far from actively informing the public of the diversion risk, lowever, the government has presented the fastbreeder as a mystery best left to experts. As President Nixon stated in announcing the second fast-breeder prototype:

Well, don't ask me what a fast breeder reactor is: Ask Dr. Schlesinger. But tell him not to tell you because unless you are one of those $\mathrm{PhD}$ 's, you wouldn't understand it either. ${ }^{147}$

VI.

\section{Obstacles to Public Participation}

Numerous court decisions have recognized the advantages flowing from public participation in agency proceedings. ${ }^{148}$ Most administrative agencies, lowever, apparently reinain hostile toward public intervention and view intervenors as ineddlers more interested in the pursuit

143. See Shapley, supra note 140 , at 143.

144. 5 U.S.C. $\$ 552$ (a) (3) (1970).

145. AEA $\$ 141,42$ U.S.C. $\$ 2161$ (1970).

146. See, e.g., speeches by Commissioner Doub, The Future of the Breeder, Its Impact on the Environment, and Regulatory Aspect, 2 AEC News ReLEASES No. 50 (1971), and Environmental and Regulatory Aspects of the Breeder Reactor, 2 AEC News Releases No. 45 (1971); speech by Commissioner Ramey, The Energy Needs of the Nation and the Costs in Terms of Pollution, 2 AEC News Releases No. 47 (1971).

147. Address by President Nixon, supra note 139.

148. E.g., Office of Communications of the United Church of Christ v. FCC, 359 F.2d 994 (D.C. Cir. 1966). 
of publicity and psychic satisfaction than the public's interest. Thus, they may focus concern on ways to check intervention. ${ }^{140}$ And public involvement is curtailed not only by the failure to disclose relevant facts; agency procedures themselves create further obstacles.

Intervenors face an uphill battle to present their views. First, they may not receive notice of the pendency of proceedings due to agency compliance with the strict letter of the law, but nothing more. For example, the FPC gave notice of the proceeding to license the famous Storm King pumped-storage plant by publication in the local newspaper of Goshen, New York. ${ }^{150}$ As another example, public participation in the formulation of state air plans was jeopardized because the agencies holding hearings on these plans gave late notice, did not broadcast the times and places of hearings, and changed the times and places at the last minute. ${ }^{151}$

Even when adequate notice is given, the amount of time granted public interest groups to organize, decide whether or not to intervene, prepare their case, and raise funds is usually very short, a matter of a few months at most, while licensing agencies and utility applicants have been preparing their position for years. Agency procedures should be redesigned to give timely, actual notice of pending proceedings, and mucls earlier public involvement should be permitted.

Once the decision to intervene is made, public interest groups find it difficult to participate effectively because of their limited funds. The cost of taking part in a plant-licensing proceeding can exceed $\$ 100,000$, consisting of fees for lawyers and expert witnesses and charges for such items as multiple copies of papers for filing. ${ }^{162}$ The FPC, for example, demands 14 copies. $^{153}$ Also, effective liearing cross-examination necessitates buymg rush transcripts of each day's proceedings, ${ }^{154}$ at \$1.38 per page for AEC proceedings and over one dollar per page for FPC proceedings. ${ }^{155}$ Charges for transcripts alone can amount to many thousands of dollars in a major proceeding.

Lack of funds is compounded by lack of access to sufficient expertise. The largest source of experts is found in the industry and the

149. Administrative Hearings, supra note 107, at 9.

150. Comment, Of Birds, Bees and the FPC, 77 YALE L.J. 117, 131-32 (1967).

151. Testimony of Richard Ayres, Director, Project on Clean Air, Natural Resources Defense Council, Inc., Hearings on Implementation of the Clean Air Amendments of 1970 before the Subcomm. on Air and Water Pollution of the Senate Comm. on Public Works, 92d Cong., 2d Sess. (Feb. 16, 1972).

152. See Administrative Hearings, supra note 107.

153. 18 C.F.R. $\$ 1.15$ (1972).

154. Green, The Risk Benefit Calculus in Nuclear Power Licensing in NUCLEAB POWER AND THE PuBLIC 133 (H. Foreman ed. 1970).

155. COMMITEE REPORT 82 n.234. 
regulatory agencies. Understandably, the former is reluctant to supply witnesses for the intervenors, and government employees are often unwilling to state their objections to proposed facilities, since to do so would place them in opposition to their employers. Officials often deny that any attempt is made to suppress dissenting staff views. As the recent AEC hearings on emergency core cooling systems suggest, however, staff opposition to agency positions often goes unexpressed, at least in part because agency executives discourage free expression of staff opinion. ${ }^{156}$

The cumulative effect of resource limitations, especially where the issues involved are technically complex, is to place the public at a major disadvantage compared to imdustry applicants, who can pass the costs of participating in agency hearings and litigation along to ratepayers. The mevitable consequence, as noted in a report to the Administrative Conference, is that

proof of scientific fact through experts is such an immensely expensive proposition that if it is left completely to the parties the contest will usually be won by well-financed interests which have a substantial monetary stake in the outcome of the proceedings. ${ }^{157}$

The effect of these resource imbalances could be lessened by appropriate agency action. Government payment for intervenors' attorneys' fees might be arranged. Agencies could also encourage experts froin their staff to meet with intervenors and testify for them, opening up to public interest groups a large source of knowledgeable opinion at minimum cost. The number of file copies required could also be reduced, and hearing transcripts could be made available to intervenors for, at most, the cost of copying.

Many other reforms would doubtless suggest themselves to an agency that wanted to implement fully the many exhortations of courts and legislatures to encourage public participation. Unfortunately, such wholehearted action is unlikely because of the desire of agencies, equipment manufacturers, and utilities to preserve their prerogative to settle issues in private bargaining. Unless such agency attitudes are changed, it is likely that any program of procedural reforms to increase public participation and public confidence in the decisionmaking process will fail.

VII.

\section{THE ENVIRONMENTALIST ROLE}

Beginning with the reversal in 1965 of the FPC's imitial license

156. See text accompanying notes 133-35 supra.

157. Boyer, supra note 109 , at 11. 
for the Storm King hydroelectric plant on the Hudson River, ${ }^{158}$ environmentalists have achieved several impressive victories over isolated power facilities, based on procedural irregularities in the licensing process. Industry and agency representatives have einphasized the significance of environmental intervention in licensing proceedings in creatimg current power supply problems, but the facts do not demonstrate either that licensing is a significant factor in delaying new plants, or that environmental opposition is important in slowing down the licensing process itself. Moreover, the environmental movement's lack of money and organization, as compared to industry, make it inevitable that past gains will be erased and future progress blocked unless the regulatory process itself undergoes fundamental change.

Before NEPA's enactinent in 1970, licensing rarely caused substantial delay. An FPC study of the 1966 to 1970 period concluded that, while many plants failed to meet scheduled start-up dates, only six percent of the delays were attributable to licensing, includimg, but not limited to, environmental objections. Over 90 percent of the delays found were attributable to either labor or equipment problems. ${ }^{159}$ Similarly, an Edison Electric Institute study of plants built between 1966 and 1968 found four delays froin licensing and no delays caused by environmental opposition, while 80 percent of the delays were attributed to labor problems, faulty equipment, and late deliveries. ${ }^{160}$ The period required to obtain an imitial decision on an AEC construction permit grew nearly $21 / 2$ times between 1966 and $1970,{ }^{161}$ but it is not clear whether any of this increase can be attributed to environmental intervention.

The enactment of NEPA, while not intended to slow the growth of electric capacity, undoubtedly las increased the time required to review license applications and thus lias contributed to delay in plant construction. No full-power operating licenses were issued by the AEC for almost a year after the Calvert Cliffs decision, which required more careful review of environmental impact: ${ }^{162}$ the Greene County decision will likewise increase the FPC's workload, as will the Zabel decision increase that of the Corps of Engineers. ${ }^{163}$ This delay, of course, is caused

158. Scenic Hudson Preservation Conf. v. FPC, 354 F.2d 608 (2d Cir. 1965), cert. denied, 384 U.S. 941 (1966).

159. Testimony of J.N. Nassikas in Hearings on Plant Siting, supra note 13, at appendix G.

160. Testimony of J.E. Moss in id. at 375.

161. E.N. Ellis and J.H. Johnston, Licensing of Nuclear Power Plants by the Atomic Energy Commission, at 21 (April 1, 1971) (a staff report to the Administrative Conference of the United States).

162. Nucleonics Week, June 1, 1972, at 4. See Calvert Cliffs Coordinating Comm. v. AEC, 449 F.2d 1109 (D.C. Cir. 1971).

163. Greene County Planning Bd. v. FPC, 455 F.2d 412 (2d Cir.), cert. denied, 
not by environmental intervention, but by the mandate of Congress to the agencies themselves. Any delay resulting from these decisions would have been lessened had the agencies not attempted to evade the impact statement requirement or to use statements prepared by the applicants instead of initially developing their own.

Even where licensing has delayed new plants, many factors other than environmental opposition have contributed substantially to the slower approval of applications. A recent analysis concluded, for example, that the major cause of increased AEC hicensing time was a doubling of the interval between the date of application and notice of a liearing, ${ }^{164}$ a period devoted to internal staff review and negotiation with the particular applicant, not public participation. A General Accounting Office study concluded that the AEC neither had nor, until recently, had requested a staff adequate to process applications with sufficient promptness. ${ }^{185}$

Another nonenvironmental cause of delay in the licensing process is the labitual filing of imcomplete apphications. The AEC regulatory staff has complamed that it has yet to receive a simgle fully complete application. Consequently, inonths are consumed in ironing out various deficiencies before formal consideration can begin. ${ }^{166}$

A third substantial factor, unrelated to environmental opposition, which causes licensing delays is the fragmented and overlapping jurisdiction of the various agencies charged with energy regulation. As an example, the impact of a nuclear plant on adjacent water quality must be considered by the AEC, the EPA, the Corps of Engineers, the state water pollution agency, and perliaps by local or regional bodies as well. Environmental advocates could take advantage of this fragmented system to delay appreciably the construction of additional plants, but they lave rarely contested a particular facility in more than one forum.

Another agency practice that causes delay, one which is associated with intervention but certamly not the fault of intervenors, is the tendency to conceal relevant information until the formal hearing, and often beyond. When intervention occurs, learings are, as a result, often prolonged by extensive discovery proceedings. Neither the AEC nor the

409 U.S. 849 (1972) (the FPC abdicated its responsibility by using a license applicant's impact statement rather than compiling its own); Zabel v. Tabb, 430 F.2d 199 (5th Cir. 1970), cert. denied, 401 U.S. 910 (1971) (NEPA requires the Corps of Engineers to prepare an environmental impact statement before it can issue a construction permit).

164. Ellis \& Johnson, supra note 161, at 21.

165. Comptroller General, supra note 115, at 4, 63.

166. Discussions with AEC staff members, January, 1972. Under proposed new AEC rules, no application can be docketed unless complete. 37 Fed. Reg. 9331 et seq. (1972). 
FPC has encouraged prehearing discovery. In the Greene County case, hitigation under the Freedom of Information Act was necessary to extract certain basic documents from the FPC. ${ }^{167}$ In a recent AEC case, the Commission refused to furnish intervenors with certain correspondence prior to the start of hearings, requiring an adjournment so that the documents could be properly examimed. ${ }^{168}$ Such attitudes make it necessary to conduct lengthy discovery during the hearing itself through the use of cross-examination. ${ }^{169}$

In sum, there is little or no evidence that the impact of environmental intervention on the licensing process has been either considerable or adverse. A recent request to the AEC for a list of projects unreasonably delayed solely because of NEPA, and where "the public interest would better liave been served by something less than full compliance with NEPA," brought forth a response naming only one project, the Quad Cities plant at Cordova, Tllinois. ${ }^{170}$ Litigation by environmental groups against that project was subsequently settled out of court. ${ }^{171}$ Similarly, a meinber of the AEC's Atomic Safety and Licensing Board has indicated that there is at present little evidence that public participation has been a major factor contributing to delays. ${ }^{172}$ In testimony on plant-siting legislation in 1971, FPC Clairman Nassikas observed that "[p]resent problems are not all, or even predominantly environmentally caused."173

Environmentalists' reliance on procedural devices in challenging utility expansion plans has met with a fair measure of initial success. Agency hicensing actions have been invalidated not because the courts disagreed with the substance of the agency decision, but because the courts felt certain relevant issues had not been considered.

But while procedural challenges have occasionally been effective in delaying construction, they can not prevent the ultimate implementa-

167. See text accompanying note 131 supra.

168. See COMMTTTEE REPORT 126.

169. The AEC, at least, has attempted to solve this problem by formulating new rules that make soine information routinely available without the need for formal discovery. 37 Fed. Reg. 9331 et seq. (1972). The new rules may achieve less than intended, however, because they still do not permit prehearing discovery until intervenors specify particular issues. And such specificity is often impossible absent prior discovery. Thus the duration of hearings may continue to be prolonged by extensive cross-examination.

170. Letter from L.M. Muntzing, AEC Director of Regulation, to R. Train, Chairman of the Council on Environmental Quatity, April 13, 1972.

171. Wall Street Journal, April 3, 1972, at 7.

172. Murphy, The National Environmental Policy Act and the Licensing Process: Environmentalist Magna Carta or Agency Coup de Grace, 72 ColUM. L. REv. 963, 994 n.129 (1972).

173. Testimony of J.N. Nassikas in Hearings on Plant Siting, supra note 13, at 72 (Detailed Basic Statement). 
tion of projects that may never have been adequately tested on the merits. Thus, although the initial licenses for the Storm King and High Mountain Sheep projects were voided, ${ }^{174}$ the licenses have been issued anew and the Storm King license has already withstood judicial review. ${ }^{175}$

Moreover, although environmental positions elicit a favorable response from the public as evidenced by the results of most opinion polls and passage of bond issues, the environmental movement is primarily represented by scattered groups marginally financed by voluntary contributions. It faces well-organized industries, composed of utilities, equipment manufacturers, and energy resource companies, which can mount powerful lobbying campaigns financed through current income. This disparity between the grass-roots political support of the environmental movement and its inadequate resources is reflected in government. The environment has reasonably large representation in Congress as a whole, but at the less visible level of most administrative action, where lobbying and the presentation of detailed proposals and criticisms can be particularly effective, the environment fairs less well. And even though agencies oriented toward the environment have begun to emerge on all levels of government, they compare unfavorably to development-oriented agencies in terms of influence, jurisdiction, and budgets.

The lack of a central agency charged with developing a comprehensive energy policy, and the current system of fragmented, overlapping, and duplicative autliority works considerable lardship and expense on both sides. But industry, with superior organization and much more money, is disadvantaged much less than environmental advocates. The imbalance between energy and environmental forces has a major impact on every aspect of the decisionmaking process, even infecting attempts, like that of the Special Committee on Electric Power and the Environment, to carry out an impartial study of that process. ${ }^{170}$

174. Scenic Hudson Preservation Conf. v. FPC, 354 F.2d 608 (2d Cir. 1965), cert. denied, 384 U.S. 941 (1966); Udall v. FPC, 387 U.S. 428 (1967).

175. Scenic Hudson Preservation Conf. v. FPC, 453 F.2d 463 (2d Cir. 1971), cert. denied, 407 U.S. 926 (1972).

176. The Association of the Bar of the City of New York meant the Special Committee on Electric Power and the Environment to be balanced and most members felt its composition was fair. But of the eleven Committee members, six were closely associated with industry or development agencies, three were partners in corporate law firms, and only two had strong ties to the environmental movement. The greater resources and organization of industry allowed it to devote much greater attention to influencing the Committee than could environmental groups.

As work proceeded, some participants had assistants review draft sections while the euvironmental advocates could not. When the Committee released its working draft for review at a public meeting, the audience included dozens of industry officials and lawyers, but only a few environmentalists could afford to attend. Industry sub- 
With licensing of specific facilities as the only available public forum, and in the absence of a comprehensive national energy policy, the environmental movement has had to use license challenges as the vehicle for consideration of problems that are and should be much broader in scope. While outgunned, environmentalists had the initial advantage of attacking an energy industry and a set of agencies unaccustomed to criticism on ecological grounds. Environmental advocates lave scored some impressive victories but, in the long run, the moveinent will be hindered by the scarcity of private and public institutions around which to rally support relative to the development-oriented organizations, and by the absence of an effective opportunity during the regulatory process to raise the issues, like the increases in power demands, which lave the greatest ultimate importance.

\section{VIII.}

\section{Current Legislative Proposals}

Although there has as yet been relatively little attention given by Congress to the development of a comprehensive national energy policy, projections for future demand have led various legislators to focus on the most easily identified symptom of a generally defective administrative process-the potential for delay in plant licensing.

Bills introduced by the Nixon Administration ${ }^{177}$ and Representative Torbert MacDonald ${ }^{178}$ have received the most attention. They deal with the licensing of all major generating and transmission facilities and ask each state to give a simgle state agency final licensing authority in order to eliminate the multiplicity of state and local clearances. The two bills also provide for federal override of the state agency when delay endangers the reliability of the electric system. Unlike the MacDonald bill, the Administration proposal makes one important change regarding the basic structure of federal licensing. It exempts federal licensing from the NEPA impact statenent requirement where the state agency has followed a "substantially coinparable procedure." Finally, each bill requires that the regional Electric Reliability Councils-private

mitted many textual critiques, some of short book length, but the environmentalists provided only one letter. Industry participation was encouraged by a trade press with yearly subscription fees of hundreds of dollars, whereas the coverage in environmental publications was proportionate to their subscription charges. Committee members affiliated with industry reported many, often heated discussions with colleagues and clients; the two environmentalists reported no significant pressure from their constituents. In short, the composition of the Committee, the climate of opinion in which it worked, and the close momitoring of its discussions by imdustry had an inevitable effect on the fimal report.

177. H.R. 5277, 92d Cong., 1st Sess. (1971).

178. H.R. 11066, 92d Cong., 1st Sess. (1971). 
bodies composed of utilities-engage in long-range planning and make their plans publicly available.

There are, of course, many differences between the bills, but their most notable feature is the gap between what they promise and what they can produce. The Administration version calls for building facilities "in a manner consonant with the preservation of important environmental values and wise comprehensive use of the Nation's . . resources" and directs the President to develop criteria for evaluating "the projected needs for electric power." the stated purposes of meeting reasonable power needs for the cominercial life of the country and the general welfare of the people as well as "reasonably to protect the environment, conserve natural resources, and plan the proper use of available lands . . . ."180 These goals would require, at a minimum, dealing with the most important issue-how much electricity should society use. But one will look in vain for an agency emipowered to implement any demand policy or any forum appropriate to formulate it. The sole exception might be the licensing hearings of the state agency. But a state-level hearing concerning a single facility is hardly the place to consider this national issue. Moreover, the only remedy available to the state agency to stem deinand is to refuse to license a specific facility. This action would still leave unresolved, however, the decisive question of which consumer demands should or would go unmet. Politically and economically, the only realistic way to deal with demand is to influence consumer and corporate choices through taxes or positive controls.

The bills also fail to provide for research and developinent into new teclinologies that might deliver electricity with less environmental harm. By contrast, Senator Magnuson has introduced a bill that would create a publicly controlled research fund financed by an electricity tax. ${ }^{181}$ This approach seems far superior to the industry alternative of industry controlling the fund since many potentially desirable teclinologies such as hoine fuel cells and solar power would threaten segments of imdustry. Nor do the MacDonald and Administration bills provide any mechanisin for choosing ainong alternative modes of generating power since separate agencies would still consider different types of facilities-for example, the FPC would still have exclusive and separate jurisdiction over hydroelectric and pumped storage plants and no control over nuclear facilities, whereas the reverse would be true of the AEC.

Whether or not a policy of discouraging energy growth is adopted,

179. H.R. $5277 \S \S 2$ (a), 9(c), 92d Cong., 1st Sess. (1971).

180. H.R. $11066 \S 2$, 92d Cong., 1st Sess. (1971).

181. Amend. No. 364 to S. 992, 92d Cong., 1st Sess. (1971). 
someone must still decide how much power is required in future years in each region and where in each region power should be produced. These decisions are important because underestimates of power requirements can lead to blackouts and overestimates can lead to waste and strong imcentives for utilities to increase the promotion of consumption. The choice of the state in which to build a new plant is also of public concern. Deciding whether New York City's power is to be produced within the city, in Vermont, or in Canada imvolves choosing which people should endure differing environmental consequences. The MacDonald and Administration bills, however, leave consideration of these important public issues to private bodies by assigning long-range planning functions to the utilities' various regional Electric Reliability Councils.

A bill introduced by Senator Hart ${ }^{182}$ and another by Representatives Eckhardt and Helstoski ${ }^{183}$ would supplant the rehability councils with regional bodies composed of representatives of various federal agencies. Neither bill provides, however, for any public proceedings or participation. A variation proposed by Representatives Dingell and Moss would require the Department of the Interior to review the longrange plans drawn by the utilities and the regional Electric Reliability Councils and then propose a national plan. ${ }^{184}$ The Dingell-Moss variation allows but does not inandate public hearings.

The one issue on which the Adininistration and MacDonald bills purport to ensure a regulatory decision is plant siting. Although the bills provide no effective governmental review of the utility's selection of a state or region in which to build a plant, they do ask the states to set up agencies to choose the best site within the selected area. Improved plant siting is an iniportant goal. But it is essentially a land-use decision that can best be made in conjunction with other land-use decisions. Therefore, it might be better to focus on electric facility siting in the pending land-use legislation. ${ }^{185}$

Although the Administration and MacDonald bills promise a coinprehensive approach to resolving the conflict between electric power and the environment, the key issues such as demand and research planning remain unaddressed. At the same time, the bills perpetuate exclusion of the public from the decisionmaking process. No effort is made to open up the ex parte negotiations, to require the disclosure of more than the limited inforination already available, to provide the

182. S. $3631,92 d$ Cong., $2 d$ Sess. (1972).

183. H.R. 13966, 92d Cong., 2d Sess. (1972).

184. H.R. 15199, 92d Cong., 2d Sess. (1972).

185. Senator Jackson's land-nse proposal, for example, fails to deal with electric facility siting. See S. 632, 92d Cong., 1st Sess. (1971). 
public with a governmental advocate at administrative proceedings, or to provide funds to hire private lawyers and expert witnesses.

Moreover, the bills would in many respects make public participation more difficult without furthering the bills' chief purpose of avoiding licensing delays. First, the Administration bill exempts federal licensing actions from the NEPA impact statement requirement, usually the public's best source of information, provided the states affected follow "substantially coinparable procedures." The bill does not define this most important phrase. But whatever the final judicial interpretation, the net result is likely to be either substantial loss of public information or further licensing delays. The states cannot duplicate the federal government's depth of staffing and experience with NEPA so that a comparable environmental impact statement will take longer to produce at the state level. Moreover, much time may be lost while the various states await a judicial determination of what "substantially comparable procedures" are.

Second, the Administration bill fails to ensure public participation when the initial choice of a site is inade-five years before construction is to begin. The bill does provide a right of public intervention during the final review of site and design-two years before construction is to begin-but the first decision point is obviously the more important since a project will gain substantial momentum in the interim. Moreover, the later that public participation begins, the greater the chance of delay.

Third, both the Administration and MacDonald bills effectively remove authority over licensing from local government, the level of government at which citizens without benefit of counsel can have the greatest impact. By withholding construction permits, local government has often been the only public body that has made a utility bend its plans to suit public opinion. On the other hand, there is a strong argument that one town should not be permitted to hold up or modify a facility that an entire region will use and pay for. But it should also be recognized that removing local government's authority changes the already uneven balance between utilities and the public. Neither bill, however, makes any atteinpt to compensate for this change.

Given the bills' apparent exacerbation of public exclusion and their failure to focus on the traditionally avoided issues of controlling deinand and promoting developinent of ecologically sound technologies, the only argument for these measures can be that they reduce delay. But while the bills' initial remedy for delay is to remove authority from individual state and local agencies, utilities have complained of delay from these levels in only a few cases. The chief complaints have been directed toward federal agencies, an area that both bills leave un- 
changed except for the NEPA exemption provided by the Administration bill. Finally, both bills will require a difficult transition period in which inuch attention will be directed toward establishing procedures and dealing with the imevitable judicial review. Neither bill inakes any provision to ease the transition.

Thus, the Administration and MacDonald bills would considerably disrupt the regulatory process to obtain questionable improvements to the questionable problem of delay, while the critical probleins remain unsolved. In short, the bills offer no ineaningful long-term solution while making it likely that delay will increase in the short-run.

IX.

\section{SUGGESTIONS FOR REFORM}

\section{A. Focusing on the Problems}

Electric power and the environment intersect with two larger public issues: energy and land use. Given the interrelationship of questions of pricing, fuel reserves, and technological development, the issues of growth of electricity use and allocation of research funds can be handled effectively only as part of an overall energy policy. At the same time, siting of specific facilities must be treated as part of an overall land-use policy.

The private sector treats energy as a unified topic. Oil companies $^{180}$ and environmental organizations have shifted their focus froin electricity alone to energy. But government structure does not follow this pattern. Lines of authority divide among various forms of energy. A reorganization should seek a unified administrative structure capable of dealing with the gamut of energy problems. Similarly, Congress should create a committee with coinprehensive jurisdiction over energy and the environment, either separately in each chamber or as a joint committee, for some of the hardest fought legislative battles are simply to determine which committee has jurisdiction over which energy problein.

The land-use question is both of national and of state and local concern. The national interest involves siting facilities in the proper region, and this issue should be handled at the federal level. But once resolved, location of the plant within the region is a inatter for state and local governments to decide, preferably through a body concerned with land-use control.

186. The largest oil companies have bought substantial holdings in coal, uranium, oil shale, natural gas, and other energy sources. 


\section{B. Separate Institutions for Different Roles}

While energy should be considered as a unified subject, one public body must not simultaneously attempt to promote energy, protect the environment, negotiate solutions, and judge the result-precisely what the FPC, the AEC, the Corps of Engineers, and state commissions attempt to do now. This conflict in roles undermines public and judicial confidence. Moreover, but not unnaturally, the commission as judge becomes defensive of the commission as promoter and adviser. Such institutional pressure causes issues to be submerged as long as possible instead of being thrust into public view and mimimizes the tension so vital to credible, accountable decisionmaking.

Prohibitions against industry-agency advisory groups or other ex parte contacts are not the answer because of the real need for continuing communication between industry and the agency as promoter and adviser. Information-gathering avenues such as the Freedom of Information Act, NEPA, and discovery cannot bring all issues into the open because getting information requires knowing of its existence and having resources to seek redress. Intra-agency differentiation of function only begins to solve the problem since conflicts in roles exist for the eommissioners themselves and within agency staff, and since job promotion and other incentives put pressure on all staff to avoid interfering with an important development.

A viable solution, on the other hand, may be to create separate institutions for separate roles-to put the tension in the process instead of in the stornachs of administrators who try to be all things to all interests. Such an approach would defime roles more clearly, bring conflicts to the surface more quickly, and yield decisions reached in an adversary setting open to public participation and scrutiny.

The functional division could involve a tripartite structure with an Agency (developing and carrying out research), an Advocate (representing environmental interests), and a Commission (making decisions on a quasi-judicial basis). The Agency would administer research and development grants for new technologies, operate government-owned facilities, plan for reliability and reserves, and advise applicants. The Advocate would administer a sinall research and development budget to review safety and environmental aspects of new projects and would represent unrepresented positions, either with its own lawyers or with outside lawyers on contract. The Commission would handle the licensing process including rulemaking and inspections and be in charge of making recommendations to Congress in such areas as demand.;

There is no guarantee that the Cominission, as the keystone, would not be dominated by one side or the other. But, at least, greater 
protection would exist than under the present structure. First, institutional rivalry would encourage the Commission to chart its own course. Second, the enabling legislation could make clear that appointments should reflect the roles of each body. Third, the budgets for each role would be explicit. Fourth, policy conflicts should receive a public airing due to the sometimes competing roles of the three bodies. Finally, a new format for negotiations would insulate the Commission and its staff froin the worst types of extra-record influence.

\section{Negotiations Should Be Opened}

The Commission's position, between the Agency and the Advocate, would help underscore the notion that it represents neither industry nor environmental interests. This notion should be reinforced by congressional guidance on what formal and informal procedures it should follow. Unlike officials of today's commissions and agencies, and like judges, the commissioners and their staff should abstain froin attending conferences and conventions of groups with business before the Commission. To minimize opportunities for political coercion, neither the Commission nor the Advocate should be subject to the jurisdiction of the Office of Management and Budget. But to ensure public accountability, perhaps the Advocate should report to a congressional committee primarily concerned with the environment.

It would be impractical to prohibit all industry-government advisory groups and other ex parte contacts that further the contimuing need for communication and joint planning. However, this function should be restricted to the Agency, for it is essential that ex parte negotiations by the Commission be forbidden. Substantive discussions between the applicant and the Commission, whether before or after the filing of any application, should be attended by a representative of the Advocate and the Agency, as well as any manageable number of ineinbers of the public that wish to attend.

\section{The Process Should Be Streamlined Without Cutting Off Debate}

Although in the past licensing has been only a minor cause of delay, its impact may grow due particularly to inultiple levels of licensing. Moreover, hearings are often drawn out because many issues are considered again and again at individual licensing hearings when they could be solved at a broader policy level.

The Special Committee on Electric Power and the Environment made suggestions that would shorten hearings by dealing with deinand, fuel cycle, and reliability issues before the licensing stage and by en- 
couraging rulemaking relating to plant design. ${ }^{187}$ A tripartite structure would also reduce discovery delays because the division between Agency, Commission, and Advocate would bring more information into the open automatically and make it available to the public at an earlier point. These structural reforms should significantly reduce delay, thereby eliminating the need for legislatively imposed methods of cutting off debate.

\section{E. A Comprehensive Solution Is Preferable to an Incremental One}

The nation is confronted with a dilemma. The Federal Power Commission warns that unless certain plants are licensed some areas will suffer power shortages. ${ }^{188}$ Other equally responsible voices claim we are in the midst of a general energy crisis that can no longer be avoided. ${ }^{189}$ Given the size of the interests at stake and considering the advantages opponents of change enjoy, a real danger exists that if current legislative proposals are enacted to ease current licensing problems, the energy crisis will not be addressed comprehensively until it becomes an energy disaster. ${ }^{190}$

The licensing and energy crises must be treated together. Delay could be costly simce the reserves of certain critical fuels can be measured in decades. Each year that additional fuel, air, and water resources are used at accelerating rates, therefore, reduces legislative flexibility. Even when a solution is enacted its impact necessarily will be slow, since the effect of prices on market behavior in the energy area is slow and price changes must initially be small so as to avoid dislocations in particular areas or industries.

It will take years to assemble the information needed to debate all the issues involved. In the meantime the nation needs new siting legislation. What we propose is an approach whereby sitmg legislation is passed but only at the same time as a legislative-administrative process begins to encourage debate and action on the total energy crisis.

This goal might be accomplished by passing in one bill (1) measures to streamline and consolidate the licensing process; (2) a federal reorganization plan that separates promotional activity and advocacy

187. See COMMITTEe REPORT 262-66.

188. See letter from FPC Chairman Nassikas to then AEC Chairman Schlesinger, Oct. 15, 1971.

189. See, e.g., Office of Emergency Preparedness, supra note 79.

190. As Senator Ted Stevens (Rep., Alaska) stated in arguing that a National Land Use bill should be passed instead of a Coastal Land Use Bill, "[o]ne of the best ways to get a bill national in scope is to make certain that you do not let the hot spots go first . . . ." Hearings on S. 582, S. 632, S. 638, S. 992, Before the Subcommittee on Oceans and Atmosphere of the Senate Committee on Commerce, 92d Cong., 1st Sess., ser. 92-15, at 264 (1971). 
functions from decisionmaking and creates a neutral commission empowered to grant a federal license for all generating facilities; and (3) a national energy act establishing an initially small tax on energy and giving this Energy Commission the authority to prepare an annual energy report and the duty to recommend to Congress increases in the tax, or more direct controls if necessary. ${ }^{191}$ Any approach narrower than the one suggested here, such as a general siting bill, could well prevent society from eventually coming to grips im a comprehensive fashion with the total crisis of energy and the environment.

\section{CONCLUSION}

The inibalance in usable political power between the electricity industry and environmental interests has resulted in fundamental breakdowns in the administrative process, whicll may well be found in other areas of regulation. First, many of the major issues are resolved by default without an explicit decision or without any single body, public or private, even purporting to balance competing interests and technologies. Second, licensing decisions, whicli represent the bulk of the conscious decisions now made by the system, are based on private negotiations shielded by lack of disclosure and other obstacles to public participation.

Yet this analysis alone places too much blame on government and industry officials. Today's system arises basically from the growth ethic that has pervaded our society from its beginnings. That ethic has engendered a multitude of private and public institutions oriented toward development and assessing their success in direct proportion to their rate of growth. The public itself has generally subscribed to this view until very recently, and large elements probably still do. Seen in this light, the basic requirement is not one of more or less public control, but rather of creating institutions, both public and private, that can balance continued growth agaimst social and ecological utility.

While legislative attention presently focuses on the need to reduce delays in the plant-hicensing process, three critical issues remain unaddressed-the lack of controls on the spiraling demand for energy, the paucity of research into ecologically sound technologies, and the importance of facilitating public participation in the administrative decisionmaking processes. This Article agrees that the licensing process should be streamlined. But it also suggests that a federal reorganiza-

191. Representative Vanik (Dem., Ohio) has introduced legislation seeking to conserve energy through taxation. H.R. 6194, 7531, 93d Cong., 1st Sess. (1973). In contrast President Nixon's recent energy messages rely on voluntary measures to curb energy consumption, while perpetuating the divisions of regulation according to the fuel or production method involved, and failing to provide for increased public participation. New York Times, June 30, 1973, at 1, col. 1. 
tion be undertaken to bring all inatters relating to electricity production before one forum and to create within that forun three separate bodies charged with resolving in an adversary manner the conflict between increasing deinands for energy and environmental protection. An Agency would develop and carry out research; an Advocate would represent environmental interests; and a Commission would conduct hearings and render decisions. Finally, this Article recommends a small tax on energy consumption as a way to begin controlling energy demand.

Certainly these recoinmendations would require greater administrative reform than current legislative proposals, but they attempt to address the root causes of the problem and, at the least, might hold out some prospect for long-term improvement. The common wisdom is that the political process permits only gradual changes in its institutions. Yet the establishment of administrative agencies themselves was a substantial departure from prior practices. The time has come to realize that the administrative process, at least as it applies to energy and the environment, does have fundamental problems, problems that cannot be solved by purely incremental solutions. Adding additional layers of authority to developinent-oriented agencies cannot prove sufficient; what is required is a basic restructuring designed to produce institutions with the ability and the desire to focus on the critical issues and to facilitate broad public participation in the decisionmaking process. 